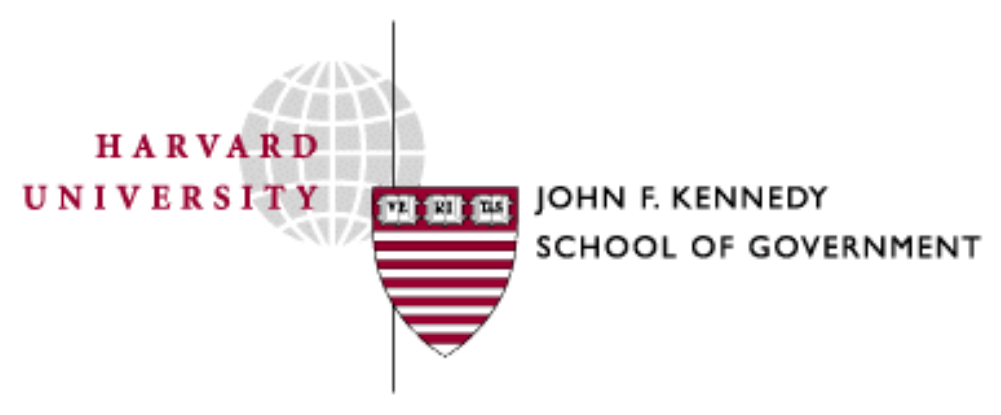

Faculty Research Working Papers Series

\author{
Inequality and Corruption \\ Jong-Sung You and Sanjeev Khagram
}

January 2004

RWP04-001

(Revised November 18, 2004)

This paper can be downloaded without charge from the Social Science Research Network at: http://ssrn.com/abstract $=489823$

It is also available from the John F. Kennedy School of Government Faculty Research Working Papers Series at: http://ksgnotes1.harvard.edu/Research/wpaper.nsf/rwp/RWP04-001

The views expressed in the KSG Faculty Research Working Paper Series are those of the author(s) and do not necessarily reflect those of the John F. Kennedy School of Government or Harvard University. Copyright belongs to the author(s) unless assigned by contract to a commercial publisher. The Research Administration Office (RAO) retains a non-exclusive right to distribute this paper to colleagues and other interested parties for personal use only. 


\title{
A Comparative Study of Inequality and Corruption*
}

\author{
You, Jong-sung \\ Harvard University
}

Sanjeev Khagram

Harvard University

(Word count: 11,540 words)

* Direct correspondence to You, Jong-sung, Ph D. candidate in Public Policy, John F. Kennedy School of Government, Harvard University, Cambridge, MA 02138

(youjong@ksg.harvard.edu). We thank Alberto Abadie, Daron Acemoglu, Christopher Jencks, Johann Graf Lambsdorff, Erzo Luttmer, John Meyer, Susan Rose-Ackerman, Suzanne Shanahan, and David Wise for their helpful comments to earlier drafts. We acknowledge Gili Drori, Rafael La Porta, Dani Rodrik, and Daniel Treisman for kindly providing their data as well as the Transparency International, the World Bank Institute, David Dollar and Aart Kraay for making their data publicly available. We also acknowledge research support provided by the Hauser Center for Nonprofit Organizations. 


\title{
A Comparative Study of Inequality and Corruption
}

\begin{abstract}
We argue that income inequality increases the level of corruption through material and normative mechanisms. The wealthy have both greater motivation and opportunity to engage in corruption, while the poor are more vulnerable to extortion and less able to monitor and hold the rich and powerful accountable as inequality increases. Inequality also adversely affects people's social norms about corruption and beliefs about the legitimacy of rules and institutions, and thereby makes it easier to tolerate corruption as acceptable behavior.

Our comparative analysis of 129 countries utilizing two-staged least squares methods with a variety of instrumental variables supports our hypotheses, using different measures of corruption (the World Bank's Control of Corruption Index and the Transparency International's Corruption Perceptions Index). The explanatory power of inequality is at least as important as conventionally accepted causes of corruption such as economic development. We also find a significant interaction effect between inequality and democracy, and evidence that inequality affects norms and perceptions about corruption, using the World Values Survey data. Since corruption also contributes to income inequality, societies often fall into vicious circles of inequality and corruption.
\end{abstract}




\section{Authors’ Biography}

You, Jong-sung is Ph. D. Candidate in Public Policy and Doctoral Fellow of Inequality and Social Policy Program at Harvard University. His dissertation research is devoted to developing a theory of corruption as injustice and conducting empirical studies on the causes of corruption and the impact of inequality and corruption on social trust and redistribution.

Sanjeev Khagram is currently Visiting Professor at the Institute for International Studies at Stanford University on sabbatical from the Kennedy School of Government at Harvard University. His research focuses on transnational dynamics and architectures of governance as well as the political economy of (democratic) governance, (sustainable) development, and (human) security.. His book, "Dams and Development: Transnational Struggles for Water and Power," was published by Cornell University Press in 2004, and he is the lead co-editor of the volume, "Restructuring World Politics: Transnational Social Movements, Networks and Norms," published by the University of Minnesota Press in 2002. 


\section{A Comparative Study of Inequality and Corruption}

Does income inequality affect corruption? This important question has seldom been addressed by social scientists. Although cross-national statistical studies on the causes of corruption have proliferated (Ades and Di Tella 1999; Treisman 2000; Paldam 2002; Montinola and Jackman 2002), sociological theorizing and research on corruption is surprisingly rare. While political scientists and economists have examined corruption primarily in relation to economic development rather than to inequality, sociologists who examine inequality have paid scant attention to the problem of corruption. As a consequence, the relationships between inequality and corruption are grossly understudied.

This article makes three sets of contributions to the literature on cross-national variation in corruption. We first offer a theoretical account for why income inequality increases corruption generally, and counterintuitively in democratic political systems. We also argue that inequality fosters a norm of corruption as acceptable behavior, corruption is likely to reinforce or widen existing inequalities, and vicious circles of inequality-corruption-inequality are thus likely to manifest.

Secondly, the predictive ability of income inequality, and the interaction between inequality and democracy, are empirically tested against competing conventional explanations of corruption. Indeed, to the best of our knowledge, this paper offers the first systematic cross-country statistical study focusing on the causal effect of income inequality on corruption. In addition, evidence on the relationship between inequality, perceptions and norms of corruption, as well as the reverse causation from corruption to inequality is provided.

The third set of contributions is methodological. Previous cross-national studies on causes of corruption have primarily utilized ordinary least squares (OLS) methods. As a result, these studies did not directly address critical issues of simultaneous causation or measurement error. We employ a range of instrumental variables and 
two-staged least squares (2SLS) methods to substantially correct for these problems. We also use a wide array of controls as well as different measures for corruption to test the robustness of our results.

We first briefly review major sets of theoretical explanations and results from previous empirical studies on corruption. In section 2, we advocate much greater attention to inequality, a factor that has received little attention by scholars. We describe the data and methods employed to investigate our hypotheses in section 3. Empirical findings and theoretical interpretations from our statistical work are presented in section 4. The final section concludes with some research and policy implications.

\section{Existing Explanations and Empirical Findings}

We utilize a somewhat narrow but widely accepted definition of corruption, i.e., abuse of public power (or public office) for private gain. Although we do not see any reasons to exclude corporate embezzlement, fraud in the non-profit sector, etc., from the definition, there are no available cross-national measures that capture this fuller range of corruption.

Until recently, statistical studies of corruption have suffered from the lack of reliable quantitative data. As the data on the (perceived) levels of corruption became available for a large number of countries, cross-country statistical research bourgeoned. Although these studies generated a considerable consensus regarding the negative effects of corruption on economic development, undermining the long-advocated functional view of corruption, studies on the causes of corruption did not produce general agreement (Lambsdorff 1999; Andvig et al. 2000). Numerous variables have been suggested as causes of corruption, which can be classified into three broad categories of economic, political, and cultural explanations.

Economic factors are often considered the prime causes of corruption. Economic development (per capita income), ostensibly through the spread of education, creation of a middle class, etc., was found to be the strongest determinant for reducing corruption in many studies (Treisman 2000; Paldam 2002). In contrast, Kaufmann and 
Kraay (2002) argued that causation ran from lower corruption to economic development and not from higher income to less corruption. Trade openness presumably through increased economic competition and economic growth was found to be significantly negatively associated with corruption by Ades and Di Tella (1999) and Treisman (2000) although, according to Torrez (2002), its significance depended on the choice of corruption index. The significance of the relative wages of public servants in controlling corruption depended on the measures and the specifications used (Rijckeghem and Weder 1997; Evans and Rauch 1999). Countries with larger endowments of natural resources were found to be significantly more corrupt, probably because windfall gains offer greater opportunities for corruption (Ades and Di Tella 1999; Leite and Weidman 1999; Gylfason 2001).

Political explanations of corruption include variables such as democracy, government size, and decentralization. Although democracy (electoral competition, political rights, etc.) is theoretically supposed to provide checks against corruption, empirical studies found differing results. ${ }^{1}$ Treisman (2000) concluded that democracies are significantly less corrupt only after 40 years. Montinola and Jackman (2002) demonstrated that the effect of democracy may be nonlinear; partial democratization may increase corruption but once past a threshold, democracy inhibits corruption. The size of government or extent of government intervention was proposed to increase corruption (LaPalombara 1994), yet empirical evidence shows that larger governments are less corrupt (La Porta et al. 1999; Friedman et al. 2000). And the findings on the effect of decentralization are contradictory (Treisman 2000; Fisman and Gatti 2002).

Cultural and historical explanations of corruption have highlighted the effects of religion, cultural values, colonial heritage, legal traditions, and ethnolinguistic fractionalization. Egalitarian or individualistic religions like Protestantism may encourage challenges to abuses by office-holders, while hierarchical religions such as Catholicism, Eastern Orthodoxy, and Islam may discourage such challenges.

\footnotetext{
${ }^{1}$ Rose-Ackerman (1999) argues that elections increase the accountability of politicians, but also produce new incentives for corruption as political financing needs increase.
} 
Protestantism's link with economic development and democracy offer two additional causal pathways. Protestantism was found to be significantly associated with less corruption by many empirical studies (La Porta et. al. 1999; Sandholtz and Koetzle 2000; Treisman 2000; Paldam 2001).

Colonial experience and legal system are closely correlated. La Porta et al. (1999) proposed that legal systems are reflective of the relative power of the state vis-à-vis property owners. While the British common law system was developed as a defense of property owners against the attempts by the sovereign to expropriate property, civil law was developed as a sovereign instrument for state building and economic control. Treisman (2000) further argued that British legal traditions tend to emphasize the procedural fairness. He found former British colonies to be significantly less corrupt. While countries with French legal or socialist origins have higher levels of corruption, legal origins are insignificant controlling for other factors (La Porta et al. 1999).

In addition, Huntington's cultural areas of Western Europe, Latin America, and Old Communist countries (Paldam 2002) and Hofstede's cultural values such as power distance, uncertainty avoidance, and masculinity (Husted 1999) were also significant predictors of corruption. Although some scholars suggested ethnolinguistic fractionalization would increase corruption (Mauro 1995), its significance disappeared after adding per capita income and latitude controls (La Porta et al. 1999).

\section{Inequality and Corruption}

The relationship between inequality and corruption was not rigorously theorized or systematically examined in any of these previous studies. Our overall argument is that greater levels of inequality are social structurally conducive through material and normative mechanisms to higher levels of corruption. Thus we should find a direct empirical relationship between inequality and corruption, controlling for other factors. We focus on income inequality in this article. ${ }^{2}$

\footnotetext{
${ }^{2}$ Two studies found a significant effect of gender equality on corruption (Swamy et al. 1999; Dollar, Fisman, and Gatti 2001). They found that women were less involved in bribery and less likely to condone the practice of taking
} 
H1 - Greater income inequality will be associated with higher levels of corruption

One of the central theoretical arguments in the literature is that corruption is a function of motivations and opportunities (Rose-Ackerman 1978, 1999; Klitgaard 1988). As income inequality increases, the rich have more to lose through fair political, administrative, and judicial processes. As inequality increases, the rich will also have greater resources that can be used to buy influence, both legally and illegally (Glaeser, Scheinkman, and Shleifer 2003). The rich as a class or interest groups can employ legal lobbying and political contributions or bribery (grand political corruption) to influence law-making processes. The rich, as interest groups, firms, or individuals may use bribery or connections to influence law-implementing processes (bureaucratic corruption) and to buy favorable interpretations of the law (judicial corruption).

As inequality increases, the majority of the population will be relatively poorer, and are likely to demand more extensive redistribution through higher levels of progressive taxation (Meltzer and Richard 1981). ${ }^{3} \quad$ As the redistributive pressures increase, the rich correspondingly have greater motivation to employ political corruption in order to lower the tax rates and bureaucratic corruption in order to further circumvent the collection of taxes.

While the rich are more motivated and capable to behave corruptly at higher levels of inequality, the non-rich have more to gain from combating corruption. The middle class and the poor generally have cause to monitor, expose, and halt the corruption by the rich and the powerful. However, the poor lack material resources to organize, and a thin middle class is likely to exert less influence in high-inequality societies. High levels of inequality (and associated poverty), holding other factors equal, is thus likely to inhibit the capacities of middle class and poor groups to monitor the corrupt activities of the rich and powerful (McCarthy and Zald 1977;

bribes. They also found that corruption was less severe where women comprise a larger share of the labor force and hold a larger share of parliamentary seats.

${ }^{3}$ Higher inequality is typically associated with greater skewness to the right as well as greater gap between the rich and the poor. 
Tarrow 1994). Greater equality is likely to entail a larger middle class that can act to protect its interests (Husted 1999).

Moreover, in high-inequality societies, the large numbers of poor are more likely to be deprived of basic public services such as education and health care than in low inequality countries. Hence, they are more likely to rely on petty corruption or be the targets of bureaucratic extortion in order to secure basic services. Although the amount of their actual payment of kickbacks may be small because of the limited ability to pay, the poor will perceive corruption levels to be very high and come to see corruption as an appropriate form of behavior.

But the impact of income inequality on corruption will differ between more democratic and less democratic countries. In countries with authoritarian regimes, the rich and the powerful can employ or promote repression to advance their interests. In democratic countries, however, oppression as a substitute for corruption cannot be employed, and hence the rich have to rely on corruption more and more as inequality increases and redistributive pressures grow. While countries with more authoritarian regimes are likely to have higher levels of corruption on average, the effect of inequality on corruption will be higher in more democratic countries.

In addition, in a highly unequal society with elections, a large number of poor people are likely to sell their votes in exchange for money, gifts, or other favors, while the rich and the powerful will buy votes in order to maintain the status quo of inequality. The poor are likely to be satisfied with small benefits by participating in petty corrupt exchanges and patronage instead of resisting grand corruption by the rich and the powerful, thus allowing them much larger benefits.

H2: The adverse effect of inequality on corruption will be larger in more democratic countries.

Human behavior is powerfully determined by values, norms, and perceptions (March and Olson 1989; Dowse and Hughes 1986). Values of integrity may differ across individuals, groups and societies. Religion may have an impact on values and norms about corruption. However, people across highly corrupt countries with widely 
different religious traditions, and even those people who engage in corruption themselves are often found to dislike corruption, combining excuse with condemnation (Miller, Grødeland and Koshechkina 2002).

Tolerance of corruption as acceptable behavior may be explained not only by religious values but also by perceptions of the extent of corruption and associated widespread social networks for corruption. If people are surrounded by corruption or perceive this to be the case, they may have to accept and even participate in corruption in spite of their values. In surveys people justify their corrupt behavior by citing its prevalence (Rose-Ackerman 2001). Corrupt transactions often require the involvement of multiple actors, and the consequent networks of corruption will offer more social structural support for participation in corrupt activities (Warburton 2001).

Correspondingly, we argue that income inequality affects people's perceptions of the extent of corruption and habituates norms about corruption. At higher levels of inequality, the rich are likely to increasingly believe that corruption is a more acceptable way of preserving and advancing their societal position as this behavior goes unpunished and social networks of corruption expand. In addition, people are more likely to consider political institutions and rules in unequal societies as favoring the rich, unjust and lacking legitimacy. More people are likely to circumvent laws and regulations when they are considered illegitimate. Thus, people will more easily justify their corrupt activities as inequality increases.

Moreover, at higher levels of inequality, most non-rich people are likely to believe that the rich and powerful must be corrupt and it is impossible to do well honestly. Hence, they are likely to justify their own corrupt behavior, in addition to finding it difficult to hold the rich and powerful accountable. As the rich and the non-rich engage in corruption, corrupt practices spread and corrupt networks further expand and deepen. Thus, corruption becomes a norm. As corrupt practices spread and are habituated as "how things are done" in highly unequal societies, the norm of corruption is socialized by subsequent generations. 
H3: Perceptions and norms on the extent and acceptability of corruption will be higher in more unequal societies.

Corruption tends to reinforce or widen already existing inequalities (Johnston 1989). Corruption contributes to inequality by facilitating the unequal appropriation of wealth and privilege and by inhibiting institutional changes that could threaten existing advantages. Thus, we expect to see a persistence of corruption with the persistence of inequality, and hence a mutually reinforcing relationship between inequality and corruption.

H4: Higher levels of corruption will be associated with higher levels of inequality.

We did not find any statistical examination specifically focused on the effect of income inequality on corruption, although two empirical studies (Husted 1999; Paldam 2002) included income inequality as one of explanatory variables and tested its effect through OLS regressions. Neither found a statistically significant effect, but this negative finding was probably the result of inefficiency and attenuation bias from measurement errors in the inequality and corruption indicators employed.

The empirical tests conducted by Husted (1999) and Paldam (2002) were far from rigorous, and both authors' primary focus was on cultural variables. Husted (1999) used Transparency International(TI)'s Corruption Perceptions Index (CPI) for 1996 and income share of the top 10\% in 1996 from the World Bank's data for a sample of only 36 countries. Paldam (2002) used TI's CPI for 1999 and gini coefficients for different years from the World Bank's data for samples of 85 to 100 countries. Both authors' OLS regressions showed only per capita income and cultural variables (cultural values for Husted and cultural areas for Paldam) were significant.

Although both studies found inequality to be insignificant, measurement error in the income inequality measures may have caused substantial attenuation bias in their estimates. Both authors used a single measure of corruption and inequality for a single year, making their results particularly vulnerable to charges of spuriousness. Husted's small sample size further raises the possibility of selection bias. 
Both authors employed OLS regressions, which cannot address potential biases associated with measurement error, omitted variables, and reverse causation. ${ }^{4}$ The relative size of reverse causality may be greater for per capita income, which will cause relative overestimation for per capita income. The measurement error is likely to be far greater for inequality, which will cause relative underestimation for inequality. Thus, we believe that there is substantial room for more rigorous statistical analysis of the effect of inequality on corruption.

The effect of corruption on inequality, in contrast, was more rigorously examined. Gupta, Davoodi, and Alonso-Terme (2002) and Li, Xu, and Zou (2000) found a significant effect of corruption on inequality through cross-country analysis. Gupta et al. (2002) suggested that corruption increased inequality by perpetuating an unequal distribution of asset ownership and unequal access to education, minimizing the progressiveness of the tax system, lowering the level and effectiveness of social spending, and by lowering economic growth.

\section{Data and Methods}

Different studies have frequently produced varying results depending on the model specifications, statistical methods as well as measures used. We address many of these problems in our analysis.

Income Inequality Measures. We use gini coefficients based on the high-quality income distribution data compiled by Dollar and Kraay (2002). They assembled data from four sources including Deininger and Squire(1996) and the UN-WIDER Income Inequality Database.

The gini coefficient ranges from 0 to 1 , where a gini of zero represents perfect equality and a gini of one means only one person or household has the total income in the country. Since income-based ginis are substantially higher than expenditure-based ginis, and differences also exist between gross income-based ginis and net income-based ginis, as well as between household-based ginis and person-based ginis,

\footnotetext{
${ }^{4}$ Paldam stated that instrumental variables 2SLS method was used for one economic sub-model, but the results were not presented.
} 
we appropriately adjusted the raw data based on different definitions to make them comparable with household net expenditure-based ginis. Our adjustments for the data are as follows. "Adjusted gini $($ GINI $)=$ gini -.0398 income -.0123 gross +.0112 person." The coefficients are based on the regression of gini on these three variables, country dummies, and decade dummies (See Appendix 1, located on the ASR website, for the details).

Since the effect of inequality on corruption is likely to be long-term, it is better to use averages over a longer period rather than data for a single year. The average values of the adjusted gini (GINI) for the period of 1971-1996, which are available for 129 countries, will be used as an independent variable when perceived corruption for the period of 1996-2002 is the dependent variable. The average values for the period of 1990s, available for 114 countries, will be used as a dependent variable when we examine the reverse causation from corruption to inequality.

In addition, by extending the period, we can also minimize measurement error. Analysis of variance (ANOVA) shows that variation within countries over time explains only $2.1 \%$ of the total variation, while variation between countries explains $91.3 \%$ of the total variation. ${ }^{5}$ A substantial part of the variation in inequality within countries across time is likely to come from measurement error, and averaging will help reduce it. ${ }^{6}$

Corruption Measures. The main indicators for corruption are the World Bank Institute (WBI)'s Control of Corruption Index (CCI) and the Transparency International (TI)'s Corruption Perceptions Index (CPI). The two data sets are regarded as the most reliable for cross-national comparisons and cover a large number of countries. We also use the Political Risk Service's (PRS) International Country Risk Guide (ICRG) index of corruption for a robustness check. ${ }^{7}$ These indices

\footnotetext{
${ }^{5} \mathrm{Li}$, Squire, and Zou (1998) also showed that $92 \%$ of the variance in Deininger and Squire (1996) data on gini coefficients for 112 countries for the years $1947-1994$ is cross-country variance, while only $1 \%$ is over-time variance. This is evidence for the persistence of income inequality across countries over time.

${ }^{6}$ Assuming that measurement error has a normal distribution with the mean of zero and variance of $\sigma^{2}$, averaging of $\mathrm{N}$ observations will reduce the variance to $\sigma^{2} / \mathrm{N}$.

${ }^{7}$ Although the ICRG index of corruption is widely used by scholars, Lambsdorff (forthcoming) warns against its reliability, noting that it measures "political risks" rather than the degrees of corruption.
} 
represent the perceived level of integrity or freedom from corruption, since a higher number indicates a lower level of corruption. The CCI is a standardized score with the mean of zero and the standard deviation of one (Kaufmann, Kraay, and Mastruzzi 2003). The CPI ranges from zero to ten (Lambsdorff forthcoming), and the ICRG index from zero to six.

We use the average values of these indices for the period from 1996 to 2002 for corruption as a dependent variable. CCI 1996-2002 (average for 1996, 1998, 2000, and 2002) is available for 195 countries including all the 129 countries for which we have the GINI 1971-96 data. CPI 1996-2002 (average for 1996-2002) is available for 109 countries. As an independent variable, CCI 1996-98 (average for 1996 and 98) and CPI 1996-99 (average for 1996-99) will be used, with the dependent variable of inequality for the period of $1990 \mathrm{~s}$.

The WBI's CCI and the TI's CPI are based on various sources of survey data, while the PRS's ICRG index of corruption is assessed by their country experts. The surveys that provide the basis of the $\mathrm{CCI}$ and the CPI mostly reflect the opinions of international business people and country experts. The various sources differently measure the perceived level of overall corruption, from the frequency of additional payments to get things done to the effects of corruption on the business environment to grand corruption. The $\mathrm{CCI}$ gives more weight to those data that are more highly correlated with the resulting aggregate index (Kaufmann et al. 2003).

Our corruption data have some limits. Neither CCI nor CPI nor ICRG provides measures for various kinds of corruption. Hence it is impossible to test whether inequality affects particular types of corruption. Moreover, cross-country ratings based on the survey respondents' (mainly international business people) perceptions or experts' subjective judgments are not only imprecise but also can be biased. Thus, measurement error and systemic bias is a particular concern. Some critics raise the specific possibility of favoring rich countries by equating richness with cleanness (Kaufmann et al. 2003). 
Yet, country corruption indices based on experts' and international business people's judgments are highly correlated with domestic public perceptions. ${ }^{8}$ And it is practically impossible to measure the actual levels of corruption across countries. We minimized the estimation inefficiency due to measurement error by using averaged data for several years (from 1996 to 2002) instead of data for a single year. We further reduced the possibility of reaching spurious conclusions by using three different measures of corruption.

Perceptions and Norms. As the measure of perceptions and norms about corruption, we use the World Values Survey, conducted between 1995-97 in 50 countries. The following four questions are relevant:

Question 1: Generally speaking, would you say that this country is run by a few big interests looking out for themselves, or that it is run for the benefit of all the people?

1) Run by a few big interests, and 2) Run for all the people.

Question 2: How widespread do you think bribe taking and corruption is in this country?

1) Almost no public officials, 2) A few public officials, 3) Most public officials, and

4) Almost all public officials are engaged in it.

For Questions 3 and 4: Tell me for each of the following statements whether you think it can always be justified (10), never justified(1), or something in between $(2-9)$.

Question 3: Cheating on taxes if you have a chance.

Question 4: Someone accepting a bribe in the course of their duties.

Control Variables. We include several economic, political, and cultural variables that were identified as significant by previous studies:

1. Economic development - Natural log of GDP per capita, average for 1971-96, calculated from the World Bank's World Development Indicators (WDI). Missing values were supplemented using La Porta et al. (1999) and Treisman (2000) dataset.

\footnotetext{
${ }^{8}$ Domestic public's perceptions on the extent of corruption (World Values Survey, 1995-97) have a correlation coefficient of .85 and .86 with the CCI and the CPI, respectively.
} 
2. Trade openness - Natural log of percentage imports plus exports over GDP, average for 1971-96, calculated from the WDI. Missing values were supplemented using La Porta et al. (1999), Treisman (2000), and Rodrik et al. (2002) dataset.

3. Natural resource abundance - Share of fuel, ore and metal exports from the total merchandise exports, average for 1971-96, calculated from the WDI.

4. Democracy - Political rights score, average for 1972-96, calculated from the Freedom House. ${ }^{9}$ The political rights score reflects (1) free and fair elections; (2) those elected rule; (3) there are competitive parties or other competitive political groups; (4) the opposition has an important role and power; and (5) the entities have self-determination or a high degree of autonomy. The original scores were converted such that a higher score represents more freedom. For countries that became independent after the collapse of Soviet Union and other former communist regimes, the political rights score for the former regimes were applied for the period before independence.

5. Federalism - The sum of five indicators of federalism, average for 1975-1996, calculated from the World Bank's Database of Political Institution (Keefer 2002): (1) the existence of autonomous regions, (2) whether municipal governments are locally elected, (3) whether state/province governments are locally elected, (4) whether the state/provinces have authority over taxing, spending or legislating, and (5) whether the constituencies of the senators are the states/provinces.

6. Religion - percentage Protestant, Catholic, and Muslim in 1980, from La Porta et al. (1999).

\section{Legal origins - English Common Law (base category), French Commercial} Code, Socialist/Communist Laws, German Commercial Code, and Scandinavian Commercial Code, from La Porta et al. (1999).

8. Ethnolinguistic fractionalization - average value of ethnic fractionalization and linguistic fractionalization, from Alesina et al. (2003).

\footnotetext{
${ }^{9}$ The Freedom House's civil liberties score or combined score of freedom rating is not used, because the checklist for civil liberties has included the existence of extreme corruption and government indifference in its fourteen elements since 1984.
} 
Instrumental variables. In order to address the potential issue of simultaneous causation as well as the problem of measurement error, we utilized instrumental variables. On the one hand, since corruption is also likely to increase inequality, OLS may overestimate the coefficient for inequality. On the other hand, measurement error in inequality may cause attenuation bias. Omitted variables bias can be either positive or negative.

Following Leigh (2003), we use "mature cohort size" relative to adult population as an instrument for inequality. Higgins and Williamson (1999) theorized the effect of cohort size on inequality. Since "fat cohorts" tend to get low rewards, when those fat cohorts lie at the top of the age-earnings curve, earnings inequality will be reduced. When the fat cohorts are old or young adults, earnings inequality is augmented. They show that the relative size of the cohort aged between 40 and 59 is a powerful predictor of inequality, both across countries and within the US.

Indeed, mature cohort size (ratio of population aged between 40 and 59 to population aged 15 through 69, averaged for 1971-96; calculated from the UN population data) is a powerful predictor of inequality (See Appendix, Table A3, on the ASR website). It is reasonable to believe that it will not directly influence or be influenced by the level of corruption other than through its effect on inequality, controlling for other variables. ${ }^{10}$ The high correlation $(r=-.72)$ between the instrument (mature cohort size) and the endogenous variable (inequality) and the presumably very weak, if any, correlation between the instrument and the error term of the regression will likely minimize the bias for the 2SLS estimator.

We also consider the endogeneity of other variables. Economic development, trade openness, and democracy may also be influenced by corruption. Democracy (political rights score) is also likely to suffer from a large measurement error, while

\footnotetext{
${ }^{10}$ One could raise doubt about our instrument by arguing that the mature cohort (those aged between 40 and 59) might have more opportunity for corruption and be more prone to corruption. However, the World Values Survey data shows that the mature cohort is slightly less, but negligibly, likely to justify bribe-taking and their perceptions about corruption are similar to the rest of population (Table 4).
} 
economic development (per capita income) and trade openness (exports plus imports over GDP) are likely to be more precisely measured.

To obtain an unbiased estimate for the inequality coefficient, we just have to control for other variables that may be correlated with mature cohort size. We do not need instruments for other endogenous variables. However, we attempted to instrument other endogenous variables as well in order to get better unbiased estimates for them and compare the results based on different sets of instruments as robustness checks. We employed reasonably good instruments for economic development and trade openness, but were unable to find a suitable one for democracy.

Following Treisman (2000), we use distance from equator (absolute value of latitude) as an instrument for economic development (per capita income). Latitude is known to be significantly associated with the levels of economic development, probably through the uneven distribution of climate (tropical vs. temperate climate) and diseases (Gallup, Sachs and Mellinger 1999; McArthur and Sachs 2001). Since we do not see any reason why latitude is directly correlated with corruption, controlling for other variables, it is a potentially useful instrument for economic development. ${ }^{11}$

Gallup and Sachs (2000) demonstrated that malaria prevalence is a strong determinant of economic development but that malaria is very geographically specific and little affected by economic development. They show evidence that the ecological conditions that support the more efficient malaria mosquito vectors primarily determine the distribution and intensity of the disease. ${ }^{12}$ Thus we use the index of malaria prevalence (the product of the fraction of land area subject to malaria times the fraction of falciparum malaria cases, average for 1966 and 1994; from Gallup and Sachs 2000) as another instrument for economic development.

\footnotetext{
${ }^{11}$ Acemoglu, Johnson, and Robinson (2001) and Rodrik, Subramanian, and Trebbi (2002) argue that quality of institutions, not geography, determines the levels of economic development. McArthur and Sachs (2001) argue that both geography and institutions matter.

${ }^{12}$ Acemoglu et al. (2001) argue that malaria prevalence is endogenous; it is the poorer countries with worse institutions that have been unable to eradicate malaria. It is beyond our scope to examine the conflicting arguments about the prevalence of malaria.
} 
We confirm that both latitude (absolute value) and malaria prevalence have very strong predictive power (Appendix Table A3). The simple correlation between latitude and per capita income is .54 , and that between malaria index and per capita income is -.63 . Jointly together, they are highly significant for economic development, controlling for other covariates. Although the exact causal relationship between geography and economic development is still being debated, these two variables are reasonably good instruments for our purposes. ${ }^{13}$

As an instrument for trade openness, we use "constructed openness" (natural logarithm of predicted trade shares from a bilateral trade equation with "pure" geography variables; computed by Rodrik et. al. 2002, following Frankel and Romer 1999). Since geography should not inherently be correlated with corruption, this is a valid instrument.

Our instruments satisfy the required statistical properties very well. The Fstatistics for the null hypothesis that the instruments are partially uncorrelated (controlling for exogenous variables) with inequality, per capita income, and openness are sufficiently high (all greater than 10), and the values of R-squared are sufficiently large (between 0.42 and 0.73; Appendix Table A3). We also conducted over-identification tests whenever it was possible. The reported P-values for the over-identification tests are generally large enough to not reject the null hypothesis that our instruments are uncorrelated with the error term of the corruption equation (Table 3 on p.30, Appendix Tables A7-A9 on the ASR website).

\section{Results and Interpretations}

First we demonstrate the utility of employing multiple measures for (freedom from) corruption and data averaged over many years for corruption and inequality. We then report and interpret our results.

\footnotetext{
${ }^{13}$ Even if we consider the possibility that latitude or malaria prevalence is correlated with the error term of the regression, i.e., $\operatorname{Corr}(z, u) \neq 0$, it is not likely to be large. Since $\operatorname{Corr}(z, x)$ is substantially large, and we suspect $\operatorname{Corr}(\mathrm{x}, \mathrm{u})$ is quite large, IV estimator is likely to be better unbiased than OLS estimator. $\mathrm{X}, \mathrm{z}$, and $\mathrm{u}$ denote, respectively, the endogenous variable (per capita income), the instrumental variables (latitude and malaria index), and the error term of the corruption regression (Wooldridge 2002).
} 
Use of averaged data and different measures of corruption:

Table 1 presents the ordinary least squares (OLS) regression results for which TI's CPI and WBI's CCI for 1998 and the average for 1996-2002 were used as the measures of corruption, the dependent variable in this analysis, and inequality (GINI), per capita income (natural log of GDP per capita), political rights score, and trade openness (natural log of percentage imports plus exports over GDP) for 1995 and the average for 1971-96 (1972-96 for political rights) ${ }^{14}$ were used as explanatory variables, controlling for the percentage Protestant in 1980.

\section{"TABLE 1 ABOUT HERE"}

For the same dependent variable measure of corruption, estimated coefficients for inequality and political rights always become larger in magnitude and more significant and those for per capita income always decrease when averaged data of the independent variables are used instead of single-year data. For CPI 98, the magnitude of the estimated standardized coefficients for inequality and political rights increases from .03 to .08 and from .03 to .24 , respectively, while the estimate for per capita income decreases from .64 to .46 , as we switch the independent variable measures from single-year to averaged data. This result suggests that OLS estimates for single-year data are biased upward for per capita income, and toward zero for inequality and political rights, because the latter two contain larger measurement error.

The table also shows that estimated coefficients for inequality and other explanatory variables vary depending on whether CPI or CCI is used as the dependent variable. Inequality is insignificant when the single-year CPI is used, while it is significant when either single-year or averaged CCI is used. This suggests that measurement errors in CPI and/or CCI are correlated with inequality and other

\footnotetext{
${ }^{14}$ Note that the Freedom House began to publish country ratings in 1972.
} 
independent variable(s). Thus the measures of (freedom from) corruption contain substantial error and may also be systemically biased.

When the averaged data are used for both the dependent and independent variables, however, inequality is significant regardless of the corruption measure controlling for per capita income, political rights, trade openness, and Protestantism. The standardized coefficients for inequality (GINI 71-96) are -.11 for CPI 96-02 and -.17 for CCI 96-02. Thus, averaging helps reduce measurement errors, although it may not solve the problem of systemic bias in corruption measures.

The influence of inequality on corruption:

We test our hypotheses in a sample of 129 countries for which both GINI (1971-96) and CCI (1996-2002) are available. For robustness checks, we compare the regression results for CCI with those based on different measures of corruption (CPI and ICRG, average for 1996-2002). ${ }^{15}$ The tables of the results for the CPI and ICRG index are presented in the Appendix on the ASR website.

Table 2 presents the OLS regression results of various specifications for a sample of 129 countries. The measures of the key four explanatory variables (inequality, per capita income, political rights, and openness) are all averaged for the period of 1971(1972) to 1996.

A striking contrast is evident between the bivariate regression (OLS 1) and the simplest multiple regression (OLS 2). The simple correlation between inequality (GINI) and control of corruption (CCI) is -.39 and highly significant. However, after including per capita income, inequality is insignificant with the standardized coefficient of -.06, while per capita income is highly significant with the standardized coefficient of .79. Is it economic development and not inequality that matters for corruption?

\section{"TABLE 2 ABOUT HERE"}

\footnotetext{
${ }^{15}$ The number of countries covered varies depending on thecorruption measure used; 102 and 110 countries are included in our sample for CPI and ICRD, respectively. Running the regressions for CCI with the sample of 102 countries or 110 countries produce similar estimates as for the sample of 129 countries.
} 
But the situation is reversed as more controls are introduced. Including either democracy (political rights) or socialist legal origin contributes to magnifying the coefficient for inequality (from -.06 to -.13 or -.23 ) and to decreasing that for per capita income (OLS 3 and 4). We see that democracy is highly positively correlated with both per capita income and (freedom from) corruption and somewhat negatively correlated with inequality (Appendix Table A2, on the ASR website). Hence, omission of this variable causes substantial upward bias for per capita income and some attenuation bias for inequality.

Countries with socialist legal origins have a significantly more equal distribution of income than others, but are significantly more corrupt on average (Appendix Table A4). The omitted variables bias from not controlling for legal origins considerably reduced the magnitude of the coefficient for inequality. Results of running the same regression as OLS 2 separately for countries with socialist vs. non-socialist legal origin demonstrate that greater inequality is significantly associated with higher corruption within both sets of countries (Appendix Table A5). Thus, failure to consider different conditions between socialist and non-socialist legal origins obscures the effect of inequality on corruption.

OLS 5 controls for openness, Protestantism, legal origins, federalism, ethnoliguistic fractionalization, and natural resource abundance as well as per capita income and political rights. ${ }^{16} 15$ countries have missing values for either natural resource abundance or federalism, so OLS 5 covers 114 countries only. In order to use the available information as fully as possible and to maintain the sample of 129 countries, we employed the method of multiple imputation for the missing data in OLS 6 (Allison 2002; King et al. 2001). ${ }^{17}$

OLS regressions 5 and 6 show that the coefficients for inequality are all statistically significant at the $1 \%$ level, and their magnitude is substantial. The

\footnotetext{
${ }^{16}$ Neither percentage Catholics nor percentage Muslims was significant. We dropped these variables in the reported regressions.

${ }^{17}$ We used King et al.'s software, Amelia (available at http://GKing.Harvard.Edu), for multiple imputation. We ran the same regressions for the five imputed data sets and combined the results to produce a single set of estimates for each regression.
} 
coefficients for inequality and other variables do not change considerably between OLS 5 and 6, and a one-standard-deviation reduction in income inequality $(0.11$ decrease in GINI) is associated with about a quarter (0.25 in OLS 5 and 0.23 in OLS 7) standard deviation improvement in corruption (as measured by CCI). Since we control for the most significant variables in previous studies, omitted variables bias is not a great concern. These estimates are arguably the best that can be obtained by using OLS regression methods.

Running the same regressions using CPI and ICRG measures of corruption as the dependent variable produces similar results. Inequality is significant for CPI and ICRG at the $1 \%$ or $5 \%$ level with the same controls as OLS 5 and 6 . A one-standard-deviation reduction in income inequality is associated with about 0.21 (or 0.26) standard deviation improvement in CPI (or ICRG) (Appendix Table A6, OLS 2 and 6).

This finding is radically different from Husted (1999) and Paldam (2002). Their use of single-year CPI and single-year measure of inequality probably produced biased results, from attenuation bias due to measurement error in inequality, inefficiency due to measurement error in CPI, and perhaps omitted variables bias and additional bias due to systemic bias in CPI. ${ }^{18}$

We also see that the standardized coefficients for per capita income are the largest and highly significant, as previous studies have consistently found. Democracy (political rights) is significant without controlling for legal origins (Table 1 and Table 2, OLS 3), but generally insignificant controlling for legal origins and other variables (Table 2, OLS 5 and 6). However, when we include a quadratic term of political rights, it is significant (OLS 8), consistent with the finding of the nonlinear effect of democracy by Montinola and Jackman (2002). Trade openness is generally insignificant or weakly positively significant for CCI, but strongly significant for CPI and ICRG (Appendix Table A6).

\footnotetext{
${ }^{18}$ It is possible that CPI does not have systemic bias and CCI has systemic bias.
} 
We see that Protestantism is significantly associated with freedom from corruption irrespective of specification and choice of corruption measure, as previous studies have found. Ethnolinguistic fractionalization is significantly associated with higher levels of corruption for CCI, but not CPI and ICRG (Appendix Table A6). Federalism and natural resource abundance are not significant.

\section{The interaction effect of inequality and democracy:}

Figure 1 demonstrates that control of corruption (CCI 96-02) and income inequality (GINI 71-96) are highly negatively correlated with each other for more democratic countries with a mean political rights score (72-96) of four or more, but the correlation is weak for less democratic countries with a score of less than four. This is consistent with our hypothesis that the effect of inequality on corruption is greater in more democratic countries.

\section{"FIGURE 1 ABOUT HERE"}

In order to more rigorously test this hypothesis, we included an interaction term of inequality (GINI) and democracy (difference from the mean political rights score of 4). We see the estimated coefficient for the interaction term is highly significant and large in OLS 7 in Table 2. A one-standard-deviation improvement in inequality (0.11 reduction in GINI) is associated with $-2.146^{*}(-0.11)=0.24$ points or 0.24 standard deviation improvement in control of corruption (CCI) at the mean political rights score of 4 . But it increases in magnitude to $\{-2.146-0.774 * 3\} *(-0.11)=0.49$ points or 0.49 standard deviation of CCI at the maximum political rights score of 7 , while it decreases as the country's political rights score declines.

The interaction term is still significant with the inclusion of a quadratic term of democracy (OLS 8). Thus the adverse effect of inequality on corruption is higher in more democratic countries even taking into account the nonlinear effect of democracy. The interaction term is also highly significant for CPI and ICRG (Appendix Table A6). 
Separate regressions also yield a highly significant and large coefficient estimate for inequality for the sample of more democratic countries, while the estimated coefficient for inequality is insignificant and small for the sample of less democratic countries (Appendix Table A8). These results support our hypothesis of greater effect of inequality on corruption in more democratic countries.

\section{The causal effect of inequality on corruption:}

We have established that a significant partial correlation between inequality and corruption exists controlling for many other plausible variables. We next used instrumental variables (IV) to provide better evidence of a causal influence from inequality to corruption and obtain even better unbiased estimates for the effect of inequality on corruption..

We will begin from the simplest IV regressions, in which only inequality (GINI) is instrumented.

$\mathrm{CCI}_{\mathrm{i}}=\beta_{0}+\beta_{1} \mathrm{GINI}_{\mathrm{i}}+\left(\mathrm{X}_{\mathrm{i}}\right)+\varepsilon_{\mathrm{i}}$

$\mathrm{GINI}_{\mathrm{i}}=\gamma_{0}+\gamma_{1}$ Mature $_{\mathrm{i}}+\left(\gamma_{2} \mathrm{X}_{\mathrm{i}}\right)+\eta_{\mathrm{i}}$

where $\mathrm{X}$ denotes covariates, and $\varepsilon$ is random error term.

The OLS estimates for $\beta_{1}$ can be biased due to omitted variables, measurement error in inequality, as well as reverse causality from corruption to inequality. A good instrument can cure all these potential biases. We instrument inequality with mature cohort size. If mature cohort size is not correlated with any other independent variables, we need not control for other variables.

However, mature cohort size is correlated with per capita income and political rights as well. Hence, we present IV estimation both with and without controls in order to compare the results with those of OLS regressions. In order to make the results comparable with those of OLS for the same sample of 129 countries, we present the IV regression results based on the multiple imputation of missing data together.

The instrumental variables two-staged least squares (IV 2SLS) estimated coefficients for inequality in Table 3 are much larger than their corresponding OLS 
estimates in Table 2, both with and without controls. Without controls, the magnitude of standardized coefficient for inequality increases from 0.39 to 0.82 (OLS 1 vs. IV 1). With the same set of controls as OLS 7, the standardized coefficient for inequality increases from 0.23 to 0.63 or 0.73 (IV 2 with listwise deletion, or IV 3 with multiple imputation), and it is significant at the $1 \%$ level. This is probably our best estimate of the causal effect of inequality on corruption.

\section{“TABLE 3 ABOUT HERE"}

The standardized coefficient for per capita income is smaller than that for inequality in IV 2 and 3. Trade openness is significant only in IV 3. In order to obtain better estimates for per capita income, trade openness, and inequality, we instrumented these three endogenous variables with four instruments of mature cohort size, latitude, malaria index, and constructed openness in IV 4 and 5. We also introduced the same set of controls as OLS 6, and employed multiple imputation for the missing data in IV 5. The estimated standardized coefficients for inequality, controlling for other factors, is -.81 (IV 4 and 5), much larger in magnitude than its OLS counterpart of -.23 . However, the standardized coefficient for per capita income is .31 or .29 , much smaller than its OLS counterpart of .49 (OLS 6). Inequality is significant at $1 \%$ level, but per capita income and trade openness are not significant.

In sum, the various IV 2SLS regressions give substantial evidence that inequality has a significant and large causal effect on corruption. A one standard deviation reduction in inequality causes about a two thirds standard deviation improvement in freedom from corruption (CCI), other factors being equal (IV 2, IV 3). The use of instrumental variables consistently increases the magnitude of the coefficient for inequality and decreases that for per capita income. Although each of our instruments may not be perfect, they are not likely to all be wrong in the same direction. ${ }^{19}$ Thus the weight of the evidence supports our hypotheses that inequality increases

\footnotetext{
${ }^{19}$ If the instruments are all wrong in the same way, they can pass the overidentification test.
} 
corruption and that large measurement error for inequality causes substantial attenuation bias in OLS. ${ }^{20}$

IV 2SLS results using other measures of corruption are also consistent with our hypotheses. These estimates for inequality are always larger than corresponding OLS estimates regardless of the corruption measure being employed, while those for per capita income are smaller than OLS estimates. We also find that the IV 2SLS estimates for inequality and per capita income differ depending on the choice of corruption measures. The estimated standardized coefficient for inequality is smallest for CPI with -.26 when only inequality is instrumented and -.33 when three endogenous variables are instrumented (Appendix Table A7, IV 2 and 4), but it is still statistically significant and larger in magnitude than its corresponding OLS estimate of -.21 (Appendix Table A6, OLS 2). IV regressions of ICRG also produced larger standardized coefficient for inequality of -.43 (with inequality only instrumented; Table A7 in Appendix on the ASR website, IV 6) or -.57 (with three variables instrumented; Table A7 in Appendix on the ASR website, IV 8) than their OLS counterpart of -.26 (Table A6 in Appendix on the ASR website, OLS 6).

A substantial part of the difference between these estimates was due to the difference in the sample, because CPI and ICRG are available for a smaller number of countries, but we cannot rule out the possibility of systemic bias in corruption measures. For example, if we run the IV 2 in Table 3 for the same sample of 91 countries for which both CPI and CCI are available, the standardized coefficients for inequality are -.38 for CCI and -.26 for CPI. Thus, the difference in the estimates is not as large as it seemed.

By using CCI as our corruption measure, the sample size was increased and selection bias was minimized. Previous studies were often based on relatively fewer countries, which raises the question of external validity. Although we cannot produce a single, reliable estimate of the causal effect of inequality on corruption, we can

\footnotetext{
${ }^{20}$ In addition, the magnitude of reverse causality from corruption to economic development is perhaps larger than that from corruption to inequality, which will cause further upward bias for per capita income.
} 
confirm the existence of a statistically significant and substantively important causal effect running from inequality to corruption.

\section{Further robustness checks:}

We conducted multiple robustness checks in addition to the use of different corruption measures. First, we ran OLS and IV regressions separately for high-income vs. low-income countries (Appendix Table A9). Both OLS and IV regressions produced significant coefficients for inequality for the sample of high-income countries, but insignificant for low-income countries. Given the high correlation between per capita income and political rights, this is understandable.

However, it raises the possibility that an interaction effect between inequality and per capita income exists and our results were biased from omitting this variable. When we included both interaction terms, the interaction of inequality with democracy outweighed that with economic development and only the former was significant (Appendix Table A10).

Second, we ran OLS and IV regressions controlling for region dummies (Appendix Table A11). Since high levels of inequality in Sub-Saharan Africa and Latin America may account for higher levels of corruption in those countries, region dummies may weaken the effect of inequality. However, inequality was generally significant even within regions. All these tests demonstrate that our findings are robust.

\section{Norms and perceptions of corruption:}

Now that we have found substantial empirical support for a causal relationship from inequality to corruption, it is important to empirically test our hypothesis of the effect of inequality on norms and perceptions about corruption, utilizing World Values Survey data. The sample covers over 36,000 individuals in 31 countries.

"TABLE 4 ABOUT HERE" 
OLS regression results in Table 4 show that people in countries with higher inequality are more likely to perceive that the society is run by a few big interests, and most public officials are corrupt. They also tend to justify bribe taking and cheating on taxes as acceptable behavior, holding individual characteristics such as income and education as well as other macro factors constant. This evidence supports our hypothesis that income inequality affects people's perceptions of the extent of corruption and habituates norms about corruption.

Interestingly, individuals in countries with higher per capita income are more likely to justify bribe taking and cheating on taxes, but their perceived extent of corruption is lower on average. Individual income has no effect on the norms. Individuals in more democratic countries are less likely to justify bribe taking, while people in countries with Socialist origin are more likely to justify bribe taking and tend to perceive more public officials are corrupt. However, religion had little impact on the norms and perceptions about corruption. ${ }^{21}$

Although women are slightly less likely to justify bribe taking and cheating on taxes than men, consistent with the finding of Swamy et al. (1999), the gender difference was negligibly small. People aged between 40 and 59 (mature cohort) were slightly (almost negligibly) less likely to justify bribe taking or cheating on taxes, and showed no difference with other people in the perceived extent of corruption.

The effect of corruption on inequality:

Our OLS regressions confirm that corruption is significantly associated with income inequality, consistent with the previous findings (Gupta et al. 2002; Li et al. 2000). We regressed inequality (average adjusted Gini for 1990s) on two measures of perceived freedom from corruption (CCI average for 1996 and 1998, and CPI average for 1996-99).

Table 5 indicates that the OLS estimated coefficients for CCI 96-98 is large and significant at the $1 \%$ level. A one standard deviation increase in CCI is associated

\footnotetext{
${ }^{21}$ We regard standardized coefficients of less than 0.05 as negligible.
} 
with a .44 standard deviation reduction in inequality for a sample of 114 countries, controlling for per capita income, political rights, trade openness, Protestantism, legal origins, ethnolinguistic fractionalization, natural resource abundance, and federalism (OLS 3). Similarly, a one standard deviation increase in CPI is associated with a .31 standard deviation reduction in inequality with the same controls for a sample of 77 countries (Appendix Table A12).

\section{"TABLE 5 ABOUT HERE"}

However, these estimates may be biased due to reverse causation as well as measurement error in corruption. Although we experimented with various sets of instruments for corruption, we were not able to find a good candidate (See Appendix 2 on the ASR website). Thus, our results are inconclusive about the causal effect of corruption on inequality. The coefficient for corruption may have been overestimated due to reverse causation, but it may also have been underestimated due to measurement error in corruption. Since these two sources of bias are likely to cancel out rather than magnify, we suspect that the effect of corruption on inequality is in fact significant.

Thus, there is evidence of reciprocal causation between inequality and corruption. Greater inequality causes higher levels of corruption, and higher levels of corruption intensify inequality. As a result, many societies are likely to be trapped in vicious circles of inequality and corruption. This mutually reinforcing relationship possibly explains why income inequality persists within countries over time.

\section{Conclusions and Implications}

In summary, income inequality is likely to be a significant and no less important determinant of corruption than economic development (and thus many other variables for that matter). The effect of inequality is likely to be greater in more democratic countries. There is also evidence that suggests that inequality fosters perceptions of 
widespread corruption and correspondingly habituates norms of corruption as "the way things are done".

Corruption is also likely to reproduce and accentuate existing inequalities. Countries may thus be trapped in vicious circles of inequality and corruption, or liberated in virtuous circles of equality and integrity (freedom from corruption).

This study identified the likely significant relationship between income inequality and corruption. Further investigation of the relationships between other kinds of inequality - in wealth, education, political participation, and social opportunities as well as gender and ethnic inequality - and corruption might be revealing as well. Our analysis also suggests that currently available cross-country measures of (perceived) corruption may have systemic and ideological bias. More work will be needed to minimize bias as well as measurement error.

Our findings may contribute to the understanding of three additional important subjects. First, corruption is likely to be an important channel through which inequality adversely affects economic growth. Inequality increases corruption, which in turn deters investment and growth. Although Alesina and Rodrik (1994) and Persson and Tabellini (1994) argued that the adverse effect of inequality on economic growth is due to high rates of taxation and redistribution, the results herein suggest an alternative explanation with corruption as a causal pathway.

Secondly, our findings may help to explain why higher levels of market-income inequality are not associated with higher levels of redistribution, contrary to the prediction of the median voter theorem (Meltzer and Richard 1981; Iversen and Soskice 2002). Inequality increases corruption, especially in democracies, and corruption produces policy outcomes closer to those preferred by the rich than those by the median voter; hence taxation and redistribution in high-inequality societies will be lower than predicted by the median voter theorem. Thus, inequality tends to persist without convergence across countries over time.

Thirdly, the significant effect of inequality on corruption may also help to explain why larger sizes of government are not associated with higher levels of corruption. One recent puzzling empirical finding was that smaller, not larger, government size 
was associated with higher levels of corruption (La Porta et al. 1999; Friedman et al. 2000), contradicting previous studies. Extensive redistribution can both increase government size and lower corruption if it effectively reduces inequality.

The corruption literature in the last decades tended to focus on the corrupt and rent-seeking behavior of public officials. When corruption is exclusively associated with the public sector, the remedy is simple: "If you want to cut corruption, cut government" (Becker 1995). But if corruption is the result of the rich attempting to preserve and advance their position, and larger government size can be associated with less corruption, minimizing the state is not necessarily the appropriate policy response.

Our study thus stresses the need for considering the motivations and opportunities for the rich and the private sector to engage in corruption (Glaeser et al. 2003; Hellman, Jones, and Kaufmann 2000). The experience of massive privatization that was accompanied by enormous corruption in Eastern European countries offers further evidence (Black, Kraakman, and Tarassova 2000; Hellman et al. 2000). We also note that the skyrocketing CEO compensation in the US, which was supposed to align the interests of CEOs to those of shareholders, not only increased income inequality but also stimulated corporate corruption as the recent scandals demonstrate.

The relationships among government size, quality, and intervention and corruption need to be further studied. What kinds of government intervention are more or less prone to different types of corruption as well as what kinds of government action are necessary to control corruption may be fruitful avenues for research. Although much of literature has stressed the need to minimize government regulations and discretion of public officials, it may be the kinds rather than quantities of regulation and discretion that are more relevant for controlling corruption.

Previous studies emphasized the role of economic development and religious and colonial traditions in determining levels of corruption. Given the persistence of cultures, one way out of corruption seemed to be economic development, but corruption is known to hinder economic development. Thus, corruption seemed to be destiny. 
However, redistribution may turn vicious circles into virtuous circles. Democracy or political equality is not sufficient to curb corruption without economic equality, and democratization in highly unequal societies may even generate increased corruption in the short run. One task of politics and public action is to shape institutions and social conditions so that people behave honestly, because they believe that the basic structure of their society is just (Elster 1987). Corruption might not be destiny after all.

\section{References}

Acemoglu, Daron, Simon Johnson, and James A. Robinson. 2001. "The Colonial Origins of Comparative Development: An Empirical Investigation.” American Economic Review 91(5): 1369-1401.

Ades, Alberto and Rafael Di Tella. 1999. "Rents, Competition and Corruption." American Economic Review 89(4): 982-994.

Alesina, Alberto F. and Dani Rodrik. 1994. "Distributive Politics and Economic Growth." The Quarterly Journal of Economics 109: 465-90.

Alesina, Alberto F., Arnaud Devleeschauwer, William Easterly, Sergio Kurlat, and Romain Wacziarg. 2003. "Fractionalization.” Journal of Economic Growth, 8: 155-194.

Allsion, Paul D. 2001. Missing Data. Thousand Oaks, CA: Sage.

Andvig, Jens. C., Odd-Helge Fjeldstad, Inge Amundsen, Tone Sissener, and Tina Søreide. 2000. "Research on Corruption: A Policy Oriented Survey." Chr. Michelsen Institute (CMI) \& Norwegian Institute of International Affairs (NUPI).

Becker, Gary S. 1995. "If You Want to Cut Corruption, Cut Government." Business Week issue 3454:26.

Black, Bernard, Reinier Kraakman, and Anna Tarassova. 2000. "Russian Privatization and Corporate Governance: What Went Wrong?” Stanford Law Review 52:1731-1808. 
Deininger, Klaus and Lyn Squire. 1996. "A New Data Set Measuring Income Inequality.” The World Bank Economic Review 10(3): 565-591.

Dollar, David, R. Fisman, and R. Gatti. 2001. “Are Women Really the 'Fairer Sex'? Corruption and Women in Government." Journal of Economic Behavior and Organization 46: 423-429.

Dollar, David and Aart Kraay. 2002. "Growth is Good for the Poor", World Bank Policy Research Paper No. 2587. Washington DC: World Bank; Journal of Economic Growth forthcoming.

Dowse, Robert E. and John A. Hughes. 1986. Political Sociology. Chichester: John Wiley \& Sons Ltd.

Elster, John. 1987. “The Possibility of Rational Politics." Archives Europeennes de Sociologie 28(1): 67-103.

Evans, Peter and James Rauch. 1999. "Bureaucracy and Growth: A Cross-National Analysis of the Effects of 'Weberian' State Structures on Economic Growth." American Sociological Review 64(5): 748-765.

Fisman, R. and R. Gatti. 2002. "Decentralization and Corruption: Evidence across Countries." Journal of Public Economics 83:325-345.

Frankel, Jeffrey, and David Romer. 1999. "Does Trade Cause Growth?” American Economic Review 89(3): 379-399.

Friedman, Eric, Simon Johnson, Daniel Kaufmann, and Pablo Zoido-Lobaton. 2000.

"Dodging the Grabbing Hand: The Determinants of Unofficial Activity in 69 Countries." Journal of Public Economics 76:459-493.

Gallup, John L. and Jeffrey D. Sachs, with Andrew D. Mellinger. 1999. "Geography and Economic Development.” CID Working Paper No. 1, Harvard University. 
Gallup, John L. and Jeffrey D. Sachs. 2000. "The Economic Burden of Malaria,” CID Working Paper No. 52, Harvard University.

Glaeser, Edward, Jose Scheinkman, and Andrei Shleifer. 2003. "The Injustice of Inequality." Journal of Monetary Economics 50:199-222.

Gylfason, Thorvaldur. 2001. "Nature, Power, and Growth." CESifo Working Paper Series No. 413.

Gupta, Sanjeev, Hamid R. Davoodi, and Rosa Alonso-Terme. 2002. "Does Corruption Affect Income Inequality and Poverty?" Economics of Governance 3(1): 23-45.

Hall, Robert E. and Charles I. Jones. 1999. "Why Do Some Countries Produce So Much More Output per Worker than Others?" Quarterly Journal of Economics CXIV(1): 83-116.

Hellman, Joel S., Geraint Jones, and Daniel Kaufmann. 2000. "Seize the State, Seize the Day: State Capture, Corruption, and Influence in Transition." World Bank Policy Research Working Paper No. 2444. Washington DC: World Bank.

Higgins, Matthew, and Jeffrey G. Williamson. 1999. "Explaining Inequality the World Round: Cohort Size, Kuznets Curves, and Openness.” NBER Working Paper 7224.

Husted, Bryan W. 1999. "Wealth, Culture, and Corruption.” Journal of International Business Studies 30(2): 339-60.

Inglehart, Ronald, et al. 2003. World Values Surveys and European Values Surveys, 1981-1984, 1990-1993, and 1995-1997 [Computer file]. ICPSR version. Ann Arbor, MI: Inter-university Consortium for Political and Social Research [distributor].

Iversen, Torben and David Soskice. 2002. "Electoral Systems and the Politics of Coalitions: Why Some Dmocracies Redistribute More than Others," Paper presented at the 2002 annual meetings of American Political Science Association.

http://www.people.fas.harvard.edu/ iversen/Iversen-Soskice2003.pdf.

Johnston, Michael. 1989. "Corruption, Inequality, and Change." in Ward, P. ed., Corruption, Development and Inequality, London and New York: Routledge 
Kaufmann, D., A. Kraay and M. Mastruzzi. 2003. "Governance Matters III: Governance Indicators for 1996-2002.” World Bank Policy Research Working Paper 3106. Washington DC: World Bank.

Keefer, Philip. 2002. "DPI 2000, Database of Political Institutions: Changes and Variable Definitions." The World Bank.

King, Gary, James Honaker, Anne Joseph, and Kenneth Scheve. 2001. "Analyzing Incomplete Political Science Data: An Alternative Algorithm for Multiple Imputation." American Political Science Review 95(1):49-69.

Klitgaard, Robert. 1988. Controlling Corruption. Berkeley: University of California Press.

Lambsdorff, J. Graf. 1999. "Corruption in Empirical Research - A Review.” Transparency International Working Paper, Berlin.

Lambsdorff, J. Graf. Forthcoming. "Measuring Corruption - The Validity and Precision of Subjective Indicators.” Measuring Corruption, International Institute for Public Ethics, Brisbane, Australia.

LaPalombara, Joseph. 1994. "Structural and Institutional Aspects of Corruption." Social Research LXI(2):325-350.

La Porta, Rafael, Florencio Lopez-de-Silanes, Andrei Schleifer, and Robert W. Vishny. 1999. “The Quality of Government." Journal of Law, Economics and Organization. 15(1):222-279.

Leigh, Andrew. 2003.”Does Equality Lead to Fraternity?" Dissertation Paper. Harvard University.

Leite, Carlos and Jens Weidmann. 1999. "Does Mother Nature Corrupt? Natural Resources, Corruption, and Economic Growth.” International Monetary Fund Working Paper No. 99/85.

Li, Hongyi, Lyn Squire, and Heng-fu Zou. 1998. "Explaining International and Intertemporal Variations in Income Inequality.” The Economic Journal 108 (January): 26-43. 
Li, Hongyi, Lixin C. Xu, and Heng-fu Zou. 2000. "Corruption, Income Distribution, and Growth.” Economics and Politics 12(2): 155-182.

March, James G. and Johan P. Olson, Rediscovering Institutions: The Organizational Basis of Politics. New York: The Free Press, 1989.

Mauro, Paolo. 1995. "Corruption and Growth.” Quarterly Journal of Economics 110(August): 681-712.

McArthur, John W. and Jeffrey D. Sachs. 2001. "Institutions and Geography: Comment on Acemoglu, Johnson and Robinson(2000).” NBER Working Paper 8114.

McCarthy, J and M. Zald. 1977. "Resource Mobilization and Social Movements: A Partial Theory." American Sociological Review 82(6):1212-1241.

Meltzer, Allan H. and Scott F. Richard. 1981. "A Rational Theory of the Size of Government." Journal of Political Economy 89:914-27.

Milanovic, Branko and Shlomo Yitzhaki. 2001. "Decomposing world income distribution: Does the world have a middle class?" The World Bank Policy Research Working Paper No. 2562.

Miller, William L., Åse B. Grødeland, and Tatyana Y. Koshechkina. 2002. "Values \& Norms versus Extortion \& Temptation." Pp. 165-193 in Corrupt Exchanges: Empirical Themes in the Politics and the Political Economy of Corruption, edited by Donatella Della Porta and Susan Rose-Ackerman. Nomos Verlagsgesellschaft, Baden-Baden.

Montinola, G. and R. Jackman. 2002. "Sources of Corruption: A Cross-Country Study." British Journal of Political Science 32:147-170.

Paldam, M. 2001."Corruption and Religion: Adding to the Economic Model." Working Paper. http://www.martin.paldam.dk.

-----. 2002. "The Cross-Country Pattern of Corruption: Economics, Culture and the Seesaw Dynamics." European Journal of Political Economy 18(2):215-240. 
Persson, Torsten and Guido Tabellini. 1994. "Is Inequality Harmful for Growth?” American Economic Review 84(3): 600-621.

Political Risk Services. International Country Risk Guide. http://www.icrgonline.com/

Rijckeghem, Caroline Van and Beatrice Weder. 1997. "Corruption and the Rate of Temptation: Do Low Wages in the Civil Service Cause Corruption?" IMF Working Paper No. 97/73, International Monetary Fund, Washington D.C.

Rodrik, Dani, Arvind Subramanian, and Francesco Trebbi. 2002. "Institutions Rule: The Primacy of Institutions over Geography and Integration in Economic Development." draft. http://ksghome.harvard.edu/ .drodrik.academic.ksg/institutionsrule,\%205.0.pdf.

Rose-Ackerman, Susan. 1978. Corruption. A Study in Political Economy. London/New York: Academic Press.

1999. Corruption and Government: Causes, Consequences and Reform. Cambridge: Cambridge University Press.

-----. 2001. "Trust and Honesty in Post-Socialist Societies." Kyklos 54: 415-444.

Sandholtz, W. and W. Koetzle. 2000. "Accounting for Corruption: Economic Structure, Democracy, and Trade.” International Studies Quarterly 44(1):31-50.

Staiger Douglas and J.H. sock. 1997. "Instrumental Variables Regression with Weak Instruments.” Econometrica 65(3): 557-86.

Swamy, A., S. Knack, Y. Lee, and O. Azfar. 1999. "Gender and Corruption”, Draft Paper, IRIS Center, University of Maryland.

Tarrow, Sidney. 1994. Power in Movement: Social Movements, Collective Action, and Politics. Cambridge: Cambridge University Press.

Torrez, Jimmy. 2002. "The Effect of Openness on Corruption.” Journal of International Trade and Economic Development 11(4):387-403. 
Transparency International, Corruption Perceptions Index (CPI), www.transparency.org/cpi/ index.html\#cpi and wwwuser.gwdg.de/ uwvw/corruption.cpi_2003.html.

Treisman, Daniel. 2000. "The Causes of Corruption: A Cross National Study." Journal of Public Economics 76:399-457.

United Nations. 2000. Demographic yearbook. Historical supplement 1948-1997 (computer file). New York: United Nations Publications.

Warburton, John. 2001. "Corruption as a Social Process: From Dyads to Networks." Pp. 221-237 in Corruption and Anti-Corruption, edited by Peter Larmour and Nick Wolanin. Canberra, Australia: Asia Pacific.

Wooldridge, Jeffrey M. 2002. Econometric Analysis of Cross Section and Panel Data. The MIT Press.

World Bank Institute. 2003. Governance Indicators: 1996-2002. www. worldbank.org/wbi/ governance/govdata2002.

\section{Figures and Tables}

Figure 1. Inequality and Freedom from Corruption in More vs. Less Democratic Countries $^{22}$

\footnotetext{
${ }^{22}$ The outlier in the figure for more democratic countries represents Namibia, which has GINI of .75.
} 


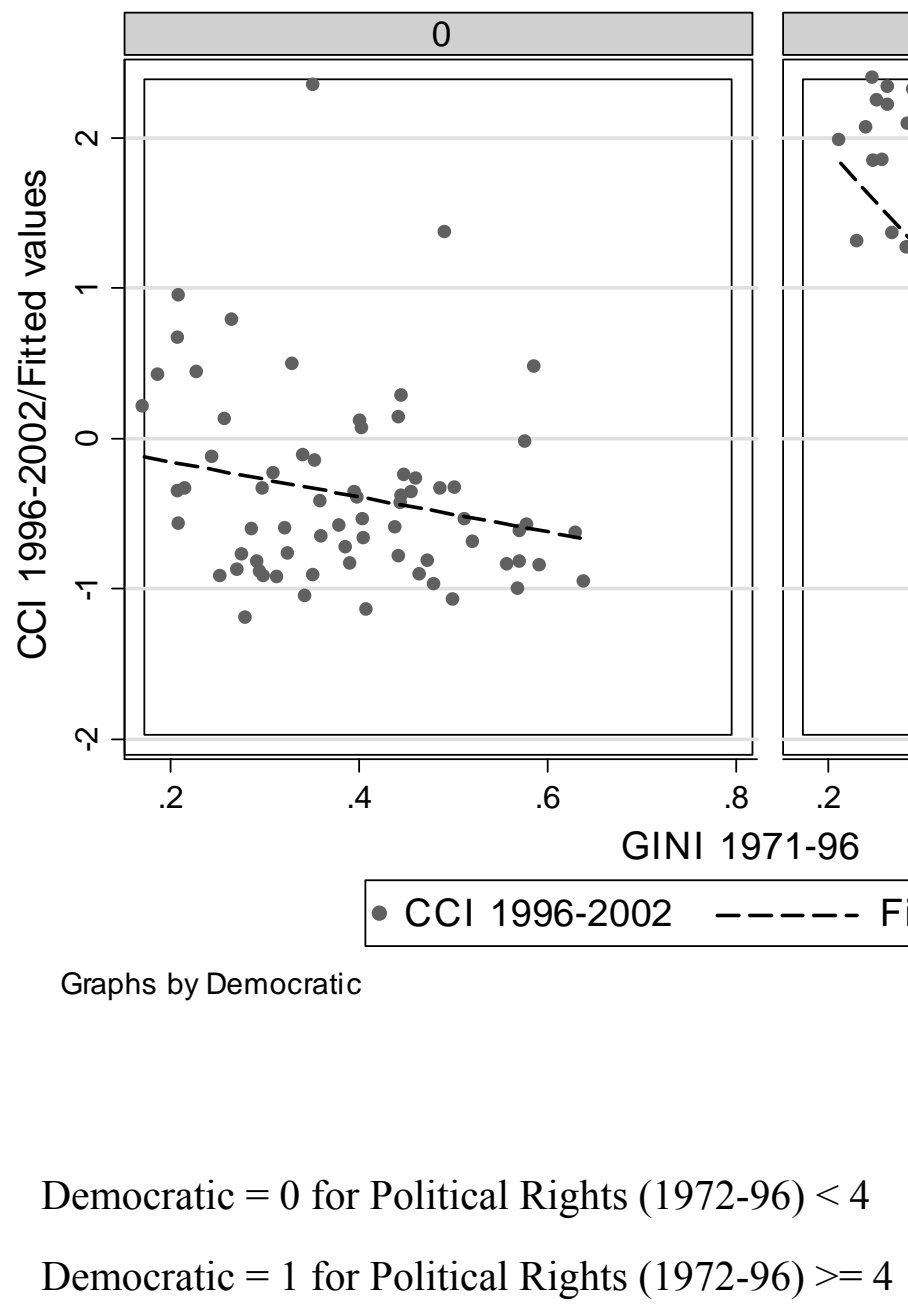


Table 1. OLS Regression Results for Single-year vs Averaged Data

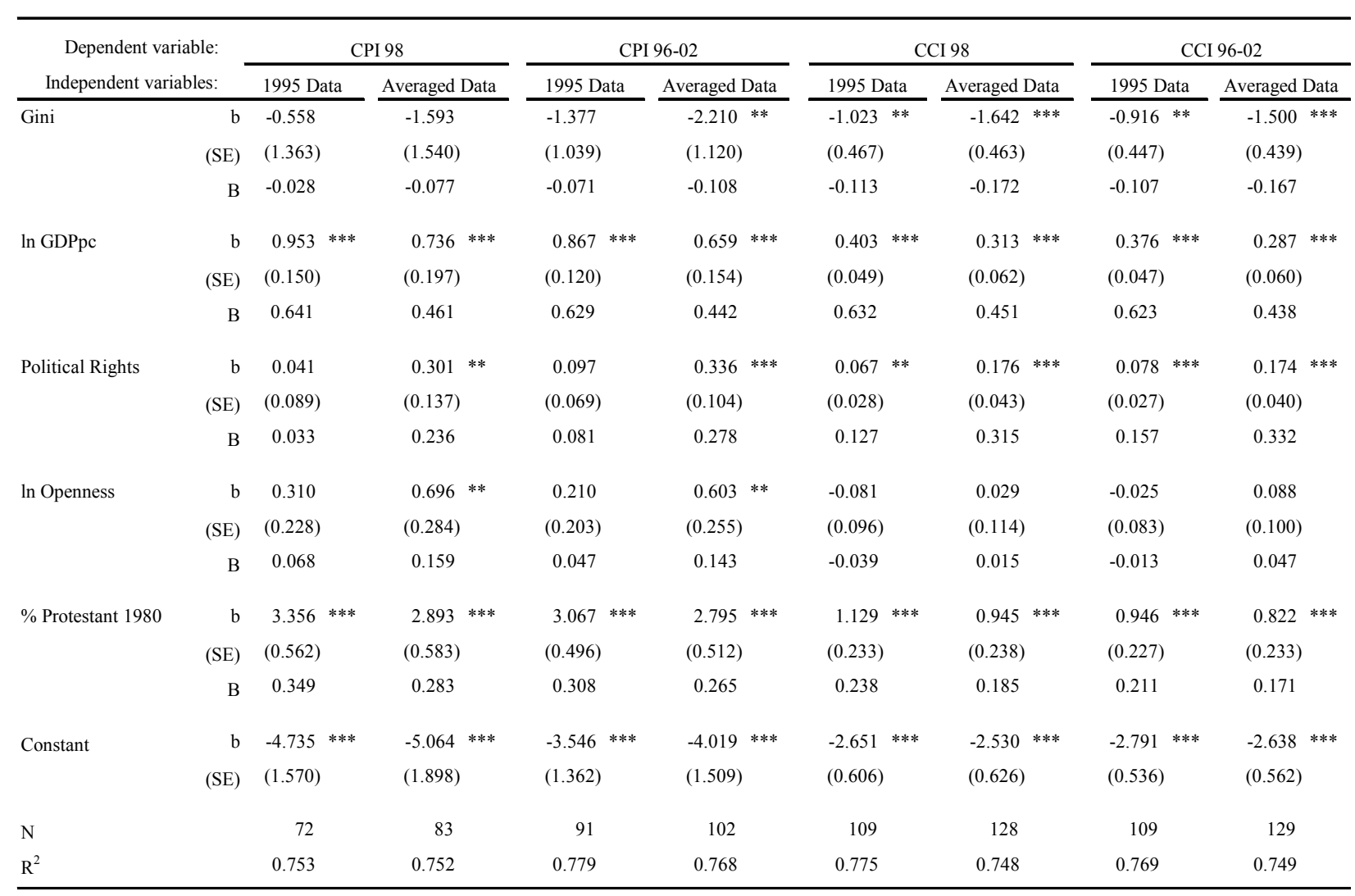

Note: For Gini, ln GDP pc, and ln Opennes, averaged data are for the period of 1971-96, and for Political Rights it is for 1972-96. For percentage Protestant, there is no averaged data. Throughout the tables, heterokedasticity-robust standard errors are presented in parentheses, and standardized coefficients (B) are given together with regression coefficients. The levels of statistical significance are denoted as follows, unless indicated otherwise; $*^{\mathrm{p}<.10,}{ }^{* *} \mathrm{p}<.05, * * * \mathrm{p}<.01$. 
Table 2. OLS Regression Results for Control of Corruption (CCI 96-02) for Various Models

\begin{tabular}{|c|c|c|c|c|c|c|c|c|c|}
\hline \multirow[b]{2}{*}{ Gini 71-96 } & Models: & OLS (1) & \multirow{2}{*}{$\begin{array}{l}\text { OLS (2) } \\
-0.569\end{array}$} & OLS (3) & OLS (4) & OLS (5) & OLS (6) & OLS (7) & OLS (8) \\
\hline & $\mathrm{b}$ & $-3.528 * * *$ & & $-1.171 * *$ & $-2.072 * * *$ & $-2.964 * * *$ & $-2.114 * * *$ & $-2.146 * * *$ & $-1.869 * * *$ \\
\hline & (SE) & $(0.782)$ & $(0.527)$ & $(0.460)$ & $(0.624)$ & $(0.684)$ & $(0.514)$ & $(0.582)$ & -0.585 \\
\hline & B & -0.392 & -0.063 & -0.130 & -0.230 & -0.304 & -0.230 & -0.240 & -0.210 \\
\hline \multirow[t]{3}{*}{ ln GDPpc 71-96 } & $\mathrm{b}$ & & $0.513 * * *$ & $0.329 * * *$ & $0.454 * * *$ & $0.337 * * *$ & $0.320 * * *$ & $0.284 * * *$ & $0.301 * * *$ \\
\hline & (SE) & & $(0.039)$ & $(0.057)$ & $(0.038)$ & $(0.074)$ & $(0.068)$ & $(0.068)$ & $(0.068)$ \\
\hline & B & & 0.785 & 0.503 & 0.695 & 0.518 & 0.490 & 0.430 & 0.460 \\
\hline \multirow[t]{3}{*}{ Political Rights 72-96 } & $\mathrm{b}$ & & & $0.188 * * *$ & & -0.004 & 0.035 & $0.347 * * *$ & -0.012 \\
\hline & (SE) & & & $(0.041)$ & & $(0.064)$ & $(0.052)$ & $(0.122)$ & $(0.235)$ \\
\hline & B & & & 0.358 & & -0.007 & 0.070 & 0.660 & -0.020 \\
\hline \multirow[t]{3}{*}{ Pol Rights Squared } & $\mathrm{b}$ & & & & & & & & $0.034 * *$ \\
\hline & (SE) & & & & & & & & $(0.017)$ \\
\hline & B & & & & & & & & 0.570 \\
\hline \multirow[t]{3}{*}{ Gini* (Pol Rights - 4) } & $\mathrm{b}$ & & & & & & & $-0.774 * * *$ & $-0.606 *$ \\
\hline & (SE) & & & & & & & $(0.301)$ & $(0.316)$ \\
\hline & B & & & & & & & -0.550 & -0.430 \\
\hline \multirow[t]{3}{*}{ Socialist legal origin } & $\mathrm{b}$ & & & & $-0.721 * * *$ & $-0.937 * * *$ & $-0.786 * * *$ & $-0.610 * * *$ & $-0.686 * * *$ \\
\hline & (SE) & & & & $(0.134)$ & $(0.265)$ & $(0.203)$ & $(0.206)$ & $(0.206)$ \\
\hline & B & & & & -0.290 & & & & \\
\hline Other controls & & No & No & No & No & Yes & Yes & Yes & Yes \\
\hline $\mathrm{N}$ & & 129 & 129 & 129 & 129 & 114 & 129 & 129 & 129 \\
\hline $\mathrm{R}^{2}$ & & 0.153 & 0.662 & 0.722 & 0.723 & 0.793 & 0.791 & 0.808 & 0.814 \\
\hline
\end{tabular}

Note: OLS 5 through 8 have additional controls such as trade openness, percentage Protestant population, French, German, and Scandinavian legal origins (British legal origin as base category), ethnolinguistic fractionalization, natural resource abundance, and federalism. The coefficients for these control variables are not reported, but those for OLS 6 are reported in Table 3. OLS 5 is based on listwise deletion, while OLS 6 through 8 are based on multiple imputation of missing data. 
Table 3. IV 2SLS Regression Results for CCI (1996-2002), Compared with OLS (6)

\begin{tabular}{|c|c|c|c|c|c|c|c|}
\hline \multirow[b]{2}{*}{ Gini 71-96 } & \multirow{3}{*}{$\begin{array}{r}\text { Models: } \\
\mathrm{b} \\
(\mathrm{SE})\end{array}$} & IV (1) & IV (2) & IV (3) & IV (4) & \multirow{2}{*}{$\frac{\operatorname{IV}(5)}{-7.334 * * *}$} & OLS (6) \\
\hline & & $-7.419 * * *$ & $-6.163 * *$ & $-6.613 * *$ & $-8.186 * * *$ & & $-2.114 * * *$ \\
\hline & & $(1.316)$ & $(2.415)$ & $(2.721)$ & $(2.954)$ & $(2.508)$ & $(0.514)$ \\
\hline & $\mathrm{B}$ & -0.820 & -0.633 & -0.730 & -0.806 & -0.810 & -0.230 \\
\hline \multirow[t]{3}{*}{ ln GDPpc 71-96 } & $\mathrm{b}$ & & $0.293 * * *$ & $0.210 * *$ & 0.197 & 0.187 & $0.320 * * *$ \\
\hline & (SE) & & $(0.081)$ & $(0.098)$ & $(0.185)$ & $(0.188)$ & $(0.068)$ \\
\hline & $\mathrm{B}$ & & 0.450 & 0.320 & 0.307 & 0.290 & 0.490 \\
\hline \multirow[t]{3}{*}{ In Open 71-96 } & $\mathrm{b}$ & & 0.181 & $0.267 *$ & 0.269 & 0.133 & $0.182 *$ \\
\hline & (SE) & & $(0.129)$ & $(0.139)$ & $(0.280)$ & $(0.247)$ & $(0.108)$ \\
\hline & B & & 0.093 & 0.140 & 0.123 & 0.070 & 0.100 \\
\hline \multirow[t]{3}{*}{ Pol Rights 72-96 } & $\mathrm{b}$ & & -0.026 & 0.003 & 0.007 & 0.020 & 0.035 \\
\hline & (SE) & & $(0.071)$ & $(0.064)$ & $(0.097)$ & $(0.089)$ & $(0.052)$ \\
\hline & B & & -0.048 & 0.010 & 0.013 & 0.040 & 0.070 \\
\hline \multirow[t]{3}{*}{$\%$ Protestant 80} & $\mathrm{~b}$ & & $0.888 * *$ & $1.415 * *$ & $1.109 *$ & $1.622 * *$ & $0.609 *$ \\
\hline & (SE) & & $(0.433)$ & $(0.640)$ & $(0.574)$ & $(0.669)$ & $(0.356)$ \\
\hline & B & & 0.188 & 0.290 & 0.227 & 0.340 & 0.130 \\
\hline \multirow[t]{3}{*}{ French legal origin } & $\mathrm{b}$ & & -0.135 & -0.135 & -0.034 & -0.122 & $-0.219 *$ \\
\hline & (SE) & & $(0.163)$ & $(0.149)$ & $(0.229)$ & $(0.194)$ & $(0.115)$ \\
\hline & B & & -0.067 & -0.070 & -0.016 & -0.060 & -0.110 \\
\hline \multirow[t]{3}{*}{ Socialist legal origin } & $\mathrm{b}$ & & $-1.399 * * *$ & $-1.386 * * *$ & $-1.464 * * *$ & $-1.407 * * *$ & $-0.786 * * *$ \\
\hline & (SE) & & $(0.461)$ & $(0.438)$ & $(0.526)$ & $(0.388)$ & $(0.203)$ \\
\hline & B & & -0.534 & -0.560 & -0.427 & -0.570 & -0.320 \\
\hline \multirow[t]{3}{*}{ German legal origin } & $\mathrm{b}$ & & -0.357 & -0.436 & -0.336 & -0.473 & -0.184 \\
\hline & (SE) & & $(0.273)$ & $(0.269)$ & $(0.300)$ & $(0.292)$ & $(0.207)$ \\
\hline & $\mathrm{B}$ & & -0.073 & -0.090 & -0.071 & -0.100 & -0.040 \\
\hline \multirow{3}{*}{$\begin{array}{l}\text { Scandinavian } \\
\text { legal origin }\end{array}$} & $\mathrm{b}$ & & -0.244 & -0.679 & -0.421 & -0.898 & 0.149 \\
\hline & (SE) & & $(0.420)$ & $(0.594)$ & $(0.489)$ & $(0.550)$ & $(0.314)$ \\
\hline & B & & -0.045 & -0.120 & -0.080 & -0.160 & 0.030 \\
\hline \multicolumn{8}{|c|}{ British legal origin (Base category) } \\
\hline \multirow{3}{*}{$\begin{array}{l}\text { Ethnolinguistic } \\
\text { fractionalization }\end{array}$} & $\mathrm{b}$ & & -0.132 & -0.337 & 0.098 & -0.340 & $-0.385 *$ \\
\hline & (SE) & & $(0.347)$ & $(0.293)$ & $(0.426)$ & $(0.322)$ & $(0.212)$ \\
\hline & B & & -0.033 & -0.080 & 0.025 & -0.080 & -0.090 \\
\hline \multirow{3}{*}{$\begin{array}{c}\text { Natural resource } \\
\text { abundance }\end{array}$} & $\mathrm{b}$ & & -0.206 & -0.152 & -0.211 & -0.127 & -0.248 \\
\hline & (SE) & & $(0.203)$ & $(0.204)$ & $(0.211)$ & $(0.193)$ & $(0.198)$ \\
\hline & B & & -0.071 & -0.050 & -0.073 & -0.040 & -0.080 \\
\hline \multirow[t]{3}{*}{ Federal } & $\mathrm{b}$ & & 0.025 & 0.022 & 0.014 & -0.005 & 0.034 \\
\hline & (SE) & & $(0.043)$ & $(0.044)$ & $(0.062)$ & $(0.055)$ & $(0.042)$ \\
\hline & $\mathrm{B}$ & & 0.043 & 0.040 & 0.024 & -0.010 & 0.060 \\
\hline \multirow[t]{2}{*}{ Constant } & $\mathrm{b}$ & $2.974 * * *$ & -0.097 & 0.305 & 0.824 & 1.259 & $-2.037 * * *$ \\
\hline & $(\mathrm{SE})$ & $(0.538)$ & $(1.268)$ & $(1.553)$ & $(1.792)$ & $(1.725)$ & $(0.525)$ \\
\hline $\mathrm{N}$ & & 127 & 114 & 129 & 98 & 129 & 129 \\
\hline \multicolumn{3}{|c|}{$P$-value for overidentification test } & & 0.168 & 0.284 & 0.763 & 0.791 \\
\hline
\end{tabular}

Note: IV regressions 1 through 3 instrumented Gini (1971-96) with Mature cohort size (1971-96). IV regressions 4 and 5 instrumented Gini (71-96), ln GDPpc (71-96), and ln Open (71-96) with Mature cohort size, Latitude, Malaria index, and Constructed openness.

IV regressions 3 and 5 and OLS 6 are based on multiple imputation of missing data. 
Table 4. Predictors of Norms and Perceptions about Corruption (OLS Estimates)

\begin{tabular}{|c|c|c|c|c|c|}
\hline \multicolumn{2}{|l|}{ Dependent variable: } & Bribe Justified & Cheat Tax Justified & Run by Big Interests & Perceived Corruption \\
\hline Gini 71-96 & $\mathrm{b}$ & 0.027 * & $0.016 *$ & $0.005 *$ & $0.006 *$ \\
\hline & (SE) & $(0.001)$ & $(0.002)$ & $(0.000)$ & $(0.001)$ \\
\hline & $\mathrm{B}$ & 0.150 & 0.070 & 0.120 & 0.070 \\
\hline Country-level variables: & & $\mathrm{B}$ & B & $\mathrm{B}$ & $\mathrm{B}$ \\
\hline Pol Rights 72-96 & & $-0.080 *$ & $-0.038 *$ & $0.070 *$ & $-0.051 *$ \\
\hline $\ln$ GDPpc 71-96 & & $0.060 *$ & $0.150 *$ & $-0.065 *$ & $-0.209 *$ \\
\hline ln Open 71-96 & & $0.035 *$ & $0.083 *$ & $0.042 *$ & $-0.071 *$ \\
\hline French legal origin & & 0.024 & 0.026 & -0.019 & $0.091 *$ \\
\hline Socialist legal origin & & $0.052 *$ & $0.184 *$ & $0.202 *$ & $0.227 *$ \\
\hline German legal origin & & 0.017 & -0.006 & $0.038 *$ & $0.046 *$ \\
\hline Scandinavian legal origin & & $0.031 *$ & $0.034 *$ & $-0.076 *$ & $-0.046 *$ \\
\hline Individual-level variables: & & $(0.018)$ & $(0.025)$ & $(0.005)$ & $(0.009)$ \\
\hline Mature (Aged 40-59) & & $-0.035 *$ & $-0.041 *$ & -0.013 & -0.001 \\
\hline Education & & $0.036 *$ & $0.052 *$ & $0.043 *$ & $-0.016 *$ \\
\hline Income & & 0.001 & 0.009 & $0.048 *$ & $0.037 *$ \\
\hline Subjective class & & 0.008 & 0.016 & $-0.077 *$ & $-0.079 *$ \\
\hline Unemployed & & $0.043 *$ & 0.036 * & 0.007 & $0.029 *$ \\
\hline Female & & $-0.041 *$ & $-0.058 *$ & $0.028 *$ & $0.018 *$ \\
\hline Catholic & & -0.019 & $-0.041 *$ & $-0.072 *$ & $-0.039 *$ \\
\hline Protestant & & -0.019 & $-0.042 *$ & $-0.034 *$ & -0.004 \\
\hline Muslim & & -0.007 & -0.009 & $0.020 *$ & $-0.021 *$ \\
\hline $\mathrm{N}$ of respondents & & 41476 & 41049 & 36530 & 40005 \\
\hline $\mathrm{N}$ of countries & & 31 & 31 & 31 & 31 \\
\hline $\mathrm{R}^{2}$ & & 0.032 & 0.076 & 0.077 & 0.146 \\
\hline
\end{tabular}

Note: Micro data are from World Values Surveys and European Values Surveys (1995-97). "Bribe justified" and "Cheating taxes justified" take the values of one to ten, "Run by big interests" zero or one, and "Perceived extent of corruption" from one to four.

* denotes significance at the 1 percent level. 
Table 5. OLS Regressions of Inequality (GINI 1990s)

\begin{tabular}{|c|c|c|c|c|c|c|c|}
\hline \multirow[b]{2}{*}{ CCI 96-98 } & Models: & \multicolumn{2}{|l|}{ OLS 1} & \multicolumn{2}{|l|}{ OLS 2} & \multicolumn{2}{|l|}{ OLS 3} \\
\hline & $\mathrm{b}$ & -4.830 & $* * *$ & -4.772 & $* * *$ & -4.963 & $* * *$ \\
\hline & (SE) & $(1.268)$ & & $(1.338)$ & & $(1.310)$ & \\
\hline & $\mathrm{B}$ & -0.430 & & -0.460 & & -0.440 & \\
\hline & & $\mathrm{B}$ & & $\mathrm{B}$ & & $\mathrm{B}$ & \\
\hline $\ln$ GDPpc 71-96 & & -0.060 & & 0.040 & & -0.050 & \\
\hline Political Rights 72-96 & & -0.140 & & -0.140 & & -0.150 & \\
\hline lnOpen 71-96 & & 0.040 & & 0.010 & & 0.040 & \\
\hline$\%$ Protestant 80 & & 0.400 & $* * *$ & 0.290 & $* * *$ & 0.410 & $* * *$ \\
\hline French legal origin & & 0.010 & & 0.060 & & 0.010 & \\
\hline Socialist legal origin & & -0.540 & $* * *$ & -0.560 & $* * *$ & -0.550 & $* * *$ \\
\hline German legal origin & & -0.140 & $* * *$ & -0.120 & $* * *$ & -0.150 & $* * *$ \\
\hline Scandinavian origin & & -0.310 & $* * *$ & -0.250 & $* * *$ & -0.320 & $* * *$ \\
\hline \multicolumn{4}{|c|}{ British legal origin (Base category) } & \multicolumn{2}{|l|}{$(4.362)$} & \multicolumn{2}{|l|}{$(4.319)$} \\
\hline \multicolumn{4}{|l|}{ Ethnolinguistic frac. } & \multicolumn{2}{|l|}{0.080} & \multicolumn{2}{|l|}{-0.020} \\
\hline \multicolumn{4}{|c|}{ Natural resource abundance } & \multicolumn{2}{|l|}{-0.030} & \multicolumn{2}{|l|}{-0.030} \\
\hline \multicolumn{4}{|l|}{ Federal } & \multicolumn{2}{|l|}{0.010} & \multicolumn{2}{|l|}{0.000} \\
\hline \multicolumn{2}{|l|}{$\mathrm{N}$} & \multicolumn{2}{|l|}{114} & \multicolumn{2}{|l|}{102} & \multicolumn{2}{|l|}{114} \\
\hline \multicolumn{2}{|l|}{$\mathrm{R}^{2}$} & \multicolumn{2}{|l|}{0.521} & \multicolumn{2}{|l|}{0.581} & \multicolumn{2}{|l|}{0.523} \\
\hline
\end{tabular}

Note: Gini index (1990s) ranges from 0 and 100. OLS 2 takes the method of listwise deletion. OLS 3 uses the whole sample of countries, for which both GINI (1990s) and CCI(96-98) are available, employing the multiple imputation for missing data. 


\section{Statistical Appendix}

\section{Adjustment of different definitions of gini coefficient}

Our adjustment is somewhat different from that of Dollar and Kraay (2002). They adjusted by subtracting .04046 from gross-income-based gini, based on the regression of gini on gross, expenditure, person, and six regional dummies. We used country dummies instead of regional dummies and added decade dummies to control for country-specific fixed effects and time effects. Our regression shows that there are significant differences between income-based and expenditure-based ginis, but that the differences between gross-income-based and net-income-based ginis as well as between person-based and household-based ginis are not very significant. We use coefficients for 'gross' and 'person' as well as 'income' dummies irrespective of statistical significance, because this will produce the best unbiased adjustment. Thus, our adjusted ginis are consistent and comparable with household net expenditure-based ginis. Our adjustment is basically consistent with Deininger and Squire(1996). They report that income-based gini is substantially higher than expenditure-based gini. Milanovic and Yitzhaki (2001) also noted that in many cases, particularly for poorer countries where direct taxes were nominal, there were practically no differences between net income and gross income. However, the differences in adjustment produced little practical difference. Our adjusted gini and Dollar and Kraay's adjusted gini showed a correlation coefficient of 0.987 .

\section{Examination of potential instruments for corruption}

We examined settler mortality rates and fraction of English speaking population as instruments for (freedom from) corruption. Acemoglu et al. (2001) used settler mortality rates as instrument for institutional quality (or risk of expropriation), 
arguing that European colonial settlers developed good institutions in places where settler mortality was low but extractive institutions in places where settler mortality was high, which had a long-lasting impact. Hall and Jones (1999) used fractions of population speaking English and western languages as the first language as instruments for institutional quality, arguing that colonial history represented by these instrumental variables matters for institutions. Since corruption is important part of the institutional quality, these variables may be good instruments for corruption.

However, these potential instruments did not have a strong partial correlation with corruption, controlling for other variables. The first-stage F-statistics was considerably smaller than the safe number of 10. It is known that the use of weak instruments can cause a severe bias (Staiger and Stock 1997; Wooldridge 2002). In addition, we have some concern that colonial history represented by these variables may have had a distributional impact as well.

Gupta et al. (2002) used English-speaking population, latitude, and ethnolinguistic fractionalization as instruments for corruption. But our experimentation invalidated the use of these instruments, because they jointly had a weak predictive power. Li et al. (2000) used Mauro (1995) measure of corruption for 1980-83 and its polynomials for instruments for ICRG index of corruption for 1982-1994 and its quadratic term. Li et al.'s instruments address the problem of measurement error and associated attenuation bias, but not the problem of simultaneity bias due to reverse causality. 
Table A1. Summary Statistics of the Variables

\begin{tabular}{lrrrrr}
\hline Variable & Obs & Mean & Std. Dev. & \multicolumn{1}{l}{ Min } & \multicolumn{1}{c}{ Max } \\
\hline Gini (avg.1971-96) & 129 & 0.386 & 0.111 & 0.173 & 0.755 \\
Gini (avg.1990-99) & 114 & 0.389 & 0.107 & 0.176 & 0.755 \\
CCI (avg. 1996-2002) & 129 & 0.112 & 1.000 & -1.205 & 2.390 \\
CPI (avg. 1996-2002) & 102 & 4.522 & 2.272 & 1.297 & 9.724 \\
ICRG (avg. 1996-2002) & 110 & 3.162 & 1.119 & 0.795 & 6.000 \\
CCI (avg. 1996-98) & 128 & 0.109 & 0.973 & -1.232 & 2.329 \\
CPI (avg. 1996-99) & 95 & 4.628 & 2.310 & 1.488 & 9.818 \\
ln GDPpc (avg. 1971-96) & 129 & 7.570 & 1.529 & 4.639 & 10.615 \\
Political Rights (avg. 1972-96) & 129 & 3.996 & 1.910 & 1.080 & 7.000 \\
lnOpen (avg. 1971-96) & 129 & 4.137 & 0.540 & 2.693 & 5.752 \\
\% Protestant (1980) & 129 & 0.125 & 0.208 & 0 & 0.978 \\
French legal origin & 129 & 0.426 & 0.496 & 0 & 1 \\
Socialist legal origin & 129 & 0.202 & 0.403 & 0 & 1 \\
German legal origin & 129 & 0.047 & 0.211 & 0 & 1 \\
Scandinavian legal origin & 129 & 0.031 & 0.174 & 0 & 1 \\
British legal origin & 129 & 0.295 & 0.458 & 0 & 1 \\
Ethnolinguistic Fractionalization & 129 & 0.413 & 0.246 & 0.002 & 0.926 \\
Natural resource abundance & 116 & 0.240 & 0.342 & 0.000 & 2.604 \\
Federal & 126 & 1.466 & 1.707 & 0.000 & 6.364 \\
Mature chort size & 127 & 0.273 & 0.047 & 0.200 & 0.365 \\
Malaria index (avg.1966 \& 94) & 120 & 0.276 & 0.396 & 0.000 & 1.000 \\
Latitude (absolute value/90) & 129 & 0.303 & 0.196 & 0.011 & 0.711 \\
Constructed openness & 114 & 2.820 & 0.766 & 0.833 & 5.639 \\
Bribe justified & 73511 & 1.7587 & 1.7633 & 1 & 10 \\
Cheating on tax justified & 72805 & 2.5010 & 2.4041 & 1 & 10 \\
Run by a few big interests & 64807 & 0.7230 & 0.4475 & 0 & 1 \\
Perceived extent of corruption & 67416 & 2.8996 & 0.8321 & 1 & 4 \\
\hline & & & & & \\
\hline
\end{tabular}


Table A2. Pairwise Correlations between Main Variables

\begin{tabular}{|c|c|c|c|c|c|c|c|c|c|c|c|c|c|c|c|c|}
\hline & (1) & (2) & (3) & (4) & (5) & (6) & (7) & (8) & (9) & (10) & (11) & (12) & (13) & (14) & (15) & (16) \\
\hline (1) $\mathrm{CCI} 96-02$ & 1 & & & & & & & & & & & & & & & \\
\hline (2) CPI 96-02 & 0.978 & 1 & & & & & & & & & & & & & & \\
\hline (3) ICRG 96-02 & 0.833 & 0.843 & 1 & & & & & & & & & & & & & \\
\hline (4) Gini 71-96 & -0.392 & -0.349 & -0.409 & 1 & & & & & & & & & & & & \\
\hline (5) $\ln$ GDPpc7196 & 0.812 & 0.812 & 0.674 & -0.418 & 1 & & & & & & & & & & & \\
\hline (6) Pol Rights 7296 & 0.733 & 0.698 & 0.648 & -0.142 & 0.708 & 1 & & & & & & & & & & \\
\hline (7) $\ln$ Open 7196 & 0.205 & 0.260 & 0.207 & -0.054 & 0.259 & 0.044 & 1 & & & & & & & & & \\
\hline (8) Protestant & 0.440 & 0.530 & 0.506 & 0.047 & 0.329 & 0.382 & 0.118 & 1 & & & & & & & & \\
\hline (9) French legal origin & -0.168 & -0.180 & -0.133 & 0.284 & -0.114 & -0.051 & -0.219 & -0.326 & 1 & & & & & & & \\
\hline (10) Socialist origin & -0.237 & -0.268 & -0.128 & -0.444 & -0.071 & -0.468 & 0.195 & -0.184 & -0.433 & 1 & & & & & & \\
\hline (11) German origin & 0.283 & 0.245 & 0.173 & -0.204 & 0.323 & 0.218 & -0.060 & 0.066 & -0.190 & -0.111 & 1 & & & & & \\
\hline (12) Scandinavian origin & 0.389 & 0.434 & 0.445 & -0.175 & 0.300 & 0.267 & 0.004 & 0.658 & -0.154 & -0.090 & -0.040 & 1 & & & & \\
\hline (13) British origin & 0.112 & 0.135 & -0.016 & 0.244 & -0.077 & 0.265 & 0.093 & 0.236 & -0.557 & -0.325 & -0.143 & -0.116 & 1 & & & \\
\hline (14) Ethnolinguistic frac. & -0.471 & -0.401 & -0.385 & 0.354 & -0.497 & -0.415 & -0.074 & -0.082 & 0.031 & -0.077 & -0.186 & -0.225 & 0.206 & 1 & & \\
\hline (15) Natural resource & -0.236 & -0.158 & -0.219 & 0.112 & -0.112 & -0.209 & 0.030 & -0.048 & 0.065 & 0.083 & -0.128 & -0.043 & -0.065 & 0.149 & 1 & \\
\hline (16) Federal & 0.403 & 0.349 & 0.286 & -0.248 & 0.431 & 0.482 & -0.341 & 0.110 & -0.025 & -0.105 & 0.262 & 0.045 & -0.020 & -0.257 & -0.116 & 1 \\
\hline
\end{tabular}


Table A3. First-stage Reduced-form Regressions of Gini, ln GDPpc, and ln Open

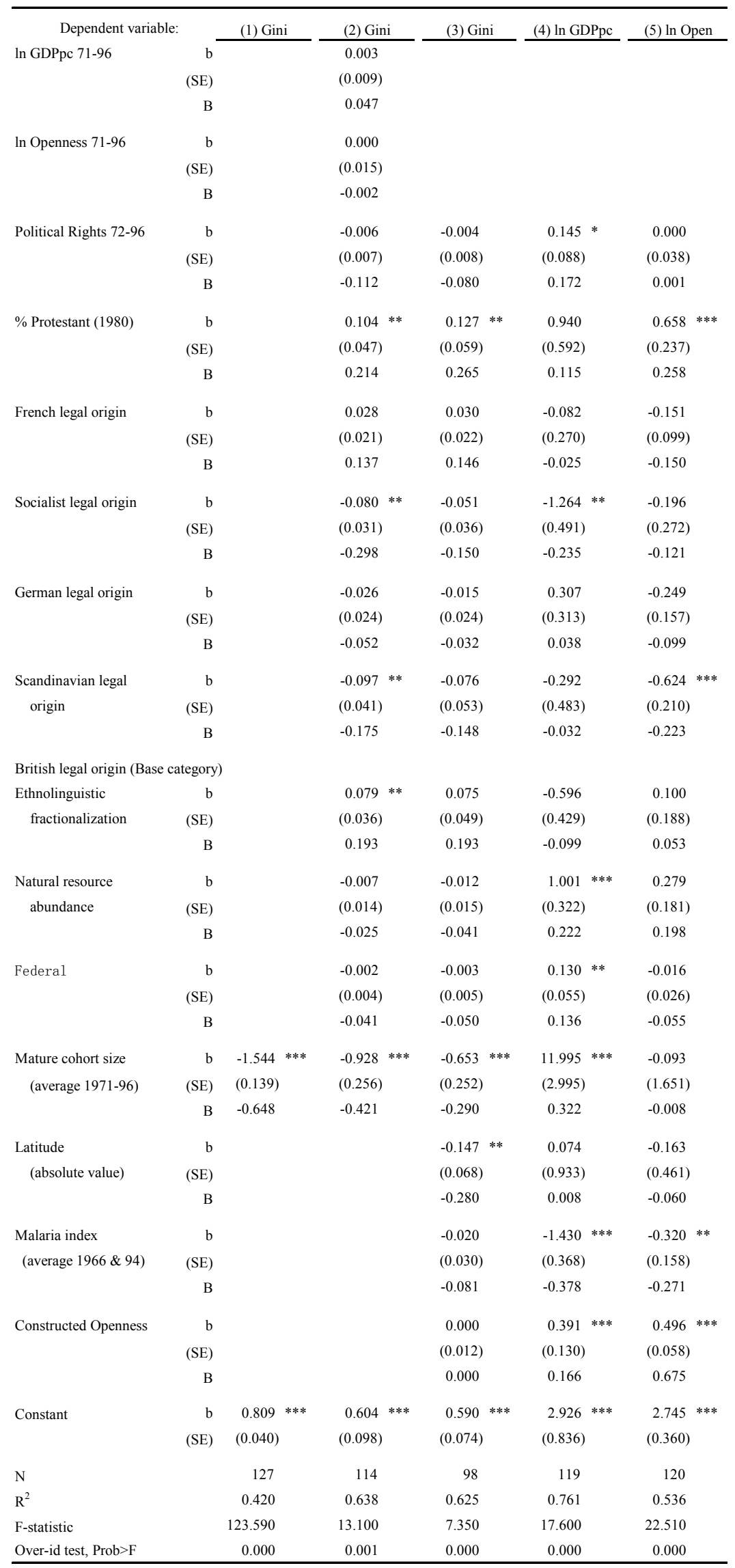

Note : Dependent variables are averages for 1971-96. F-statistics are for Ho: Mature cohort size $=0$ for the first two regressions, and Ho: Mature $=$ Latitude $=$ Malaria index $=$ Constructed openness $=0$ for the rest. 
Table A4. Separate Summary Statistics for

Countries with Socialist vs. Non-Socialist Legal Origin

\begin{tabular}{|c|c|c|c|c|c|c|}
\hline \multirow[b]{2}{*}{ Variable } & \multicolumn{2}{|c|}{ Socialist origin } & \multicolumn{2}{|c|}{ Non-Socialist origin } & \multicolumn{2}{|c|}{ Total Sample } \\
\hline & Mean & $\mathrm{N}$ & Mean & $\mathrm{N}$ & Mean & $\mathrm{N}$ \\
\hline CCI 96-02 & -0.358 & 26 & 0.231 & 103 & 0.112 & 129 \\
\hline CPI 96-02 & 3. 428 & 24 & 4. 858 & 78 & 4. 522 & 102 \\
\hline Gini 71-96 & 0.288 & 26 & 0.411 & 103 & 0.386 & 129 \\
\hline In GDPpc 71-96 & 7. 355 & 26 & 7. 624 & 103 & 7. 570 & 129 \\
\hline
\end{tabular}

Table A5. Separate Regression Results for

Countries with Socialist vs. Non-Socialist Legal Origin

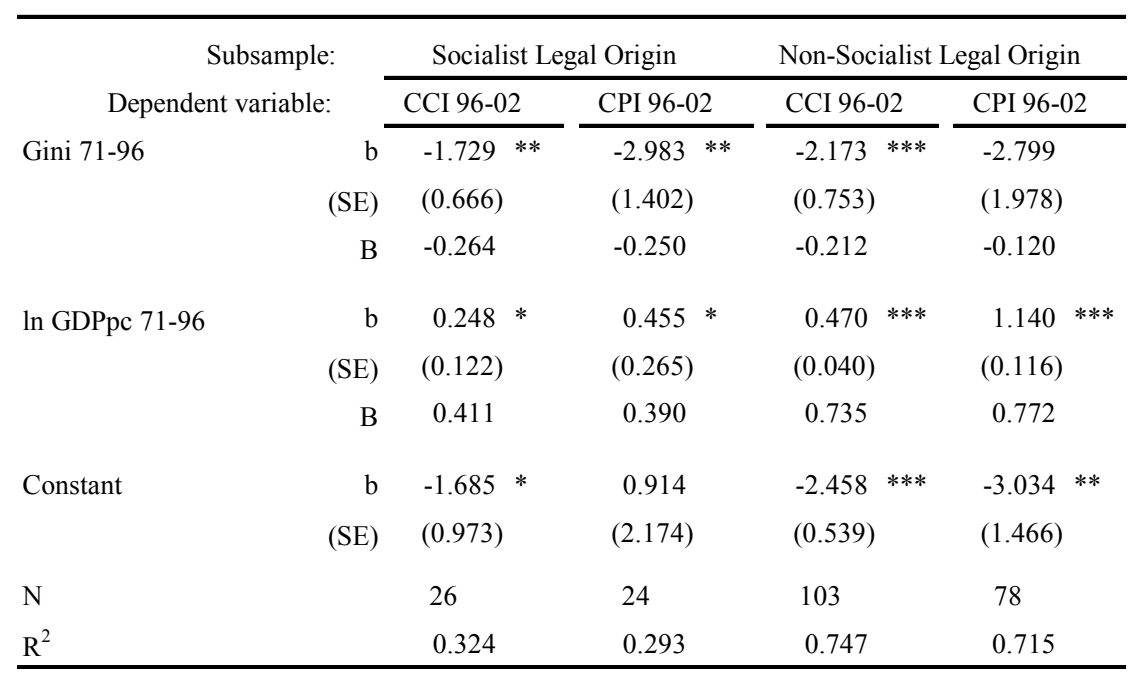


Table A6. OLS Regression Results for CPI 96-02 and ICRG 96-02

\begin{tabular}{|c|c|c|c|c|c|c|c|c|c|c|c|c|c|c|c|c|c|}
\hline \multirow{4}{*}{$\begin{array}{l}\text { Dependent varia } \\
\text { Gini } 71-96\end{array}$} & \multirow{4}{*}{$\begin{array}{r}\mathrm{e}: \\
\mathrm{b} \\
(\mathrm{SE})\end{array}$} & \multicolumn{8}{|c|}{ CPI 1996-2002 } & \multicolumn{8}{|c|}{ ICRG 1996-2002 } \\
\hline & & \multicolumn{2}{|l|}{ OLS (1) } & \multicolumn{2}{|c|}{ OLS (2) } & \multicolumn{2}{|c|}{ OLS (3) } & \multicolumn{2}{|c|}{ OLS (4) } & \multicolumn{2}{|c|}{ OLS (5) } & \multicolumn{2}{|c|}{ OLS (6) } & \multicolumn{2}{|c|}{ OLS (7) } & \multicolumn{2}{|l|}{ OLS (8) } \\
\hline & & -3.972 & $* * *$ & -4.723 & $* * *$ & -4.239 & $* * *$ & -3.470 & $* *$ & -2.993 & $* * *$ & -2.804 & $* *$ & -2.749 & $* *$ & -3.183 & $* * *$ \\
\hline & & (1.214) & & $(1.753)$ & & $(1.602)$ & & (1.534) & & $(0.915)$ & & (1.196) & & (1.105) & & (1.136) & \\
\hline & B & -0.195 & & -0.209 & & -0.188 & & -0.154 & & -0.303 & & -0.260 & & -0.255 & & -0.296 & \\
\hline \multirow[t]{3}{*}{ ln GDPpc 71-96 } & $\mathrm{b}$ & 0.772 & $* * *$ & 0.775 & $* * *$ & 0.700 & $* * *$ & 0.735 & $* * *$ & 0.110 & & 0.148 & & 0.088 & & 0.075 & \\
\hline & (SE) & $(0.170)$ & & $(0.192)$ & & $(0.178)$ & & $(0.171)$ & & $(0.097)$ & & $(0.099)$ & & $(0.095)$ & & $(0.094)$ & \\
\hline & B & 0.517 & & 0.516 & & 0.467 & & 0.490 & & 0.153 & & 0.202 & & 0.120 & & 0.102 & \\
\hline \multirow[t]{3}{*}{ Political Rights 72-96 } & $\mathrm{b}$ & 0.035 & & -0.084 & & 1.321 & $* * *$ & 0.308 & & 0.194 & $* *$ & 0.184 & $* *$ & 0.747 & $* * *$ & 1.263 & $* * *$ \\
\hline & (SE) & $(0.121)$ & & $(0.153)$ & & $(0.373)$ & & $(0.665)$ & & $(0.075)$ & & $(0.079)$ & & $(0.219)$ & & $(0.477)$ & \\
\hline & B & 0.029 & & -0.067 & & 1.063 & & 0.248 & & 0.325 & & 0.300 & & 1.216 & & 2.055 & \\
\hline \multirow[t]{3}{*}{ Pol Rights Squared } & $\mathrm{b}$ & & & & & & & 0.087 & $*$ & & & & & & & -0.044 & \\
\hline & (SE) & & & & & & & $(0.052)$ & & & & & & & & $(0.039)$ & \\
\hline & B & & & & & & & 0.640 & & & & & & & & -0.642 & \\
\hline \multirow[t]{3}{*}{ Gini* (Pol Rights -4) } & $\mathrm{b}$ & & & & & -3.573 & $* * *$ & -2.938 & $* * *$ & & & & & -1.366 & $* *$ & -1.719 & $* * *$ \\
\hline & (SE) & & & & & $(0.905)$ & & $(0.952)$ & & & & & & $(0.540)$ & & $(0.606)$ & \\
\hline & B & & & & & -0.983 & & -0.809 & & & & & & -0.801 & & -1.008 & \\
\hline lnOpen 71-96 & $\mathrm{b}$ & 0.665 & $* * *$ & 0.819 & $* * *$ & 0.806 & $* * *$ & 0.771 & $* *$ & 0.275 & $* *$ & 0.339 & $* *$ & 0.369 & $* *$ & 0.373 & $* *$ \\
\hline & (SE) & $(0.224)$ & & $(0.274)$ & & $(0.292)$ & & $(0.295)$ & & $(0.119)$ & & $(0.147)$ & & $(0.153)$ & & $(0.153)$ & \\
\hline & B & 0.157 & & 0.183 & & 0.180 & & 0.172 & & 0.131 & & 0.151 & & 0.165 & & 0.167 & \\
\hline$\%$ Protestant 80 & $\mathrm{~b}$ & 2.549 & $* * *$ & 2.462 & $* *$ & 1.677 & $* *$ & 1.488 & $*$ & 1.597 & $* * *$ & 1.648 & $* * *$ & 1.513 & $* * *$ & 1.635 & $* * *$ \\
\hline & (SE) & $(0.919)$ & & $(0.971)$ & & $(0.812)$ & & $(0.826)$ & & $(0.585)$ & & $(0.599)$ & & $(0.547)$ & & $(0.536)$ & \\
\hline & B & 0.242 & & 0.235 & & 0.160 & & 0.142 & & 0.308 & & 0.314 & & 0.289 & & 0.312 & \\
\hline French legal origin & $\mathrm{b}$ & -0.757 & $* * *$ & -0.769 & $* *$ & -0.588 & $*$ & -0.620 & $* *$ & 0.288 & & 0.332 & $*$ & 0.381 & $* *$ & 0.409 & $* *$ \\
\hline & (SE) & $(0.279)$ & & $(0.305)$ & & $(0.312)$ & & $(0.300)$ & & $(0.186)$ & & $(0.190)$ & & $(0.185)$ & & $(0.184)$ & \\
\hline & B & -0.164 & & -0.167 & & -0.128 & & -0.134 & & 0.128 & & 0.146 & & 0.167 & & 0.180 & \\
\hline Socialist legal origin & $\mathrm{b}$ & -1.901 & $* * *$ & -2.423 & $* * *$ & -1.305 & $*$ & $-1.497=$ & $* *$ & -0.131 & & -0.196 & & 0.260 & & 0.349 & \\
\hline & (SE) & $(0.442)$ & & $(0.576)$ & & $(0.681)$ & & $(0.680)$ & & $(0.266)$ & & $(0.335)$ & & $(0.353)$ & & $(0.355)$ & \\
\hline & B & -0.357 & & -0.434 & & -0.233 & & -0.268 & & -0.045 & & -0.065 & & 0.086 & & 0.115 & \\
\hline German legal origin & $\mathrm{b}$ & -0.833 & $*$ & -1.057 & $*$ & -1.215 & $* *$ & -1.211 & $* *$ & -0.039 & & -0.083 & & -0.188 & & -0.185 & \\
\hline & (SE) & $(0.497)$ & & $(0.559)$ & & $(0.532)$ & & $(0.502)$ & & $(0.235)$ & & $(0.265)$ & & $(0.291)$ & & $(0.289)$ & \\
\hline & B & -0.087 & & -0.106 & & -0.122 & & -0.122 & & -0.008 & & -0.016 & & -0.036 & & -0.035 & \\
\hline Scandinavian legal & $\mathrm{b}$ & -0.493 & & -0.336 & & -0.257 & & -0.252 & & 0.295 & & 0.190 & & 0.049 & & 0.024 & \\
\hline origin & (SE) & $(0.862)$ & & $(0.928)$ & & $(0.686)$ & & $(0.707)$ & & $(0.546)$ & & $(0.547)$ & & $(0.465)$ & & $(0.456)$ & \\
\hline & B & -0.042 & & -0.030 & & -0.023 & & -0.023 & & 0.050 & & 0.033 & & 0.009 & & 0.004 & \\
\hline British legal origin ( $\mathrm{Ba}$ & categor & & & & & & & & & & & & & & & & \\
\hline Ethnolinguistic & $\mathrm{b}$ & -1.013 & & -1.028 & & -1.130 & & -1.229 & $*$ & -0.087 & & 0.051 & & -0.087 & & -0.037 & \\
\hline fractionalization & (SE) & $(0.665)$ & & $(0.761)$ & & $(0.682)$ & & $(0.652)$ & & $(0.355)$ & & $(0.382)$ & & $(0.361)$ & & $(0.360)$ & \\
\hline & B & -0.107 & & -0.111 & & -0.122 & & -0.133 & & -0.020 & & 0.011 & & -0.020 & & -0.008 & \\
\hline Natural resource & $\mathrm{b}$ & & & -0.683 & & -0.420 & & -0.444 & & & & -0.660 & $* *$ & -0.546 & $*$ & -0.483 & \\
\hline abundance & (SE) & & & $(0.635)$ & & $(0.590)$ & & $(0.591)$ & & & & $(0.316)$ & & $(0.325)$ & & $(0.331)$ & \\
\hline & B & & & -0.068 & & -0.042 & & -0.044 & & & & -0.155 & & -0.129 & & -0.114 & \\
\hline Federal & $\mathrm{b}$ & & & 0.130 & & 0.105 & & 0.068 & & & & -0.014 & & -0.019 & & -0.003 & \\
\hline & (SE) & & & $(0.104)$ & & $(0.098)$ & & $(0.097)$ & & & & $(0.055)$ & & $(0.052)$ & & $(0.054)$ & \\
\hline & B & & & 0.105 & & 0.085 & & 0.055 & & & & -0.022 & & -0.030 & & -0.006 & \\
\hline Constant & $\mathrm{b}$ & -1.992 & & -1.856 & & -7.322 & $* * *$ & -5.142 & $* *$ & 1.262 & & 0.801 & & -1.236 & & -2.322 & \\
\hline & (SE) & $(1.612)$ & & (1.885) & & $(2.184)$ & & $(2.527)$ & & $(0.839)$ & & $(0.913)$ & & $(1.381)$ & & (1.671) & \\
\hline $\mathrm{N}$ & & 102 & & 91 & & 91 & & 91 & & 110 & & 101 & & 101 & & 101 & \\
\hline $\mathrm{R}^{2}$ & & 0.806 & & 0.806 & & 0.836 & & 0.841 & & 0.637 & & 0.650 & & 0.673 & & 0.678 & \\
\hline
\end{tabular}


Table A7. IV 2SLS Regression Results for CPI 96-02 and ICRG 96-02

\begin{tabular}{|c|c|c|c|c|c|c|c|c|c|c|c|c|c|}
\hline \multicolumn{2}{|c|}{ Dependent variable: } & \multicolumn{6}{|c|}{ CPI 1996-2002 } & \multicolumn{6}{|c|}{ ICRG 1996-2002 } \\
\hline \multirow{4}{*}{ Gini 71-96 } & \multirow{3}{*}{$\begin{array}{r}\mathrm{b} \\
(\mathrm{SE})\end{array}$} & \multicolumn{2}{|l|}{ IV (1) } & IV (2) & IV (3) & \multicolumn{2}{|l|}{ IV (4) } & \multicolumn{2}{|l|}{ IV (5) } & IV (6) & IV (7) & \multicolumn{2}{|l|}{ IV (8) } \\
\hline & & -5.960 & $*$ & -5.912 & $-8.857 *$ & -7.807 & $*$ & -5.506 & $* *$ & -4.680 & -5.771 & -6.419 & $*$ \\
\hline & & (3.439) & & $(3.852)$ & $(5.074)$ & $(4.656)$ & & $(2.112)$ & & $(3.107)$ & $(3.652)$ & $(3.856)$ & \\
\hline & $\mathrm{B}$ & -0.291 & & -0.262 & -0.407 & -0.329 & & -0.554 & & -0.435 & -0.553 & -0.568 & \\
\hline \multirow[t]{3}{*}{ ln GDPpc 71-96 } & $\mathrm{b}$ & 0.724 & $* * *$ & $0.762 * * *$ & 0.527 & 0.784 & $* *$ & 0.052 & & 0.120 & 0.082 & 0.123 & \\
\hline & (SE) & -0.187 & & -0.187 & -0.402 & -0.362 & & -0.105 & & -0.096 & -0.221 & -0.233 & \\
\hline & $\mathrm{B}$ & 0.484 & & 0.508 & 0.361 & 0.530 & & 0.072 & & 0.163 & 0.115 & 0.169 & \\
\hline \multirow[t]{3}{*}{ ln Open 71-96 } & $\mathrm{b}$ & 0.703 & $* * *$ & $0.822 * * *$ & 0.540 & 0.469 & & 0.315 & $* *$ & $0.357 * *$ & $0.479 *$ & 0.420 & \\
\hline & (SE) & $(0.228)$ & & $(0.276)$ & $(0.351)$ & $(0.404)$ & & $(0.129)$ & & $(0.150)$ & $(0.264)$ & $(0.328)$ & \\
\hline & $\mathrm{B}$ & 0.166 & & 0.184 & 0.121 & 0.098 & & 0.151 & & 0.160 & 0.210 & 0.171 & \\
\hline \multirow[t]{3}{*}{ Pol Rights 72-96 } & $\mathrm{b}$ & -0.001 & & -0.106 & 0.029 & -0.122 & & 0.151 & $*$ & 0.159 & 0.140 & 0.164 & \\
\hline & (SE) & $(0.141)$ & & $(0.183)$ & $(0.201)$ & $(0.231)$ & & $(0.088)$ & & $(0.101)$ & $(0.105)$ & $(0.110)$ & \\
\hline & $\mathrm{B}$ & -0.001 & & -0.085 & 0.023 & -0.095 & & 0.253 & & 0.259 & 0.229 & 0.260 & \\
\hline \multirow[t]{3}{*}{$\%$ Protestant 80} & $\mathrm{~b}$ & 2.921 & $* *$ & $2.588 * *$ & $4.025 * * *$ & 2.958 & $* *$ & 2.064 & $* * *$ & $1.861 * * *$ & $1.952 * *$ & 1.979 & $* * *$ \\
\hline & (SE) & (1.140) & & $(1.022)$ & $(1.520)$ & $(1.264)$ & & $(0.671)$ & & $(0.653)$ & $(0.873)$ & $(0.737)$ & \\
\hline & B & 0.277 & & 0.247 & 0.383 & 0.276 & & 0.398 & & 0.355 & 0.373 & 0.367 & \\
\hline \multirow[t]{3}{*}{ French legal origin } & $\mathrm{b}$ & -0.710 & $* *$ & $-0.726 * *$ & -0.585 & -0.633 & & 0.332 & $*$ & $0.387 *$ & 0.331 & 0.475 & \\
\hline & (SE) & $(0.295)$ & & $(0.335)$ & $(0.408)$ & $(0.409)$ & & $(0.193)$ & & $(0.201)$ & $(0.255)$ & $(0.248)$ & \\
\hline & B & -0.153 & & -0.158 & -0.125 & -0.135 & & 0.147 & & 0.170 & 0.145 & 0.204 & \\
\hline \multirow[t]{3}{*}{ Socialist legal origin } & $\mathrm{b}$ & -2.214 & $* * *$ & $-2.617 * * *$ & $-2.284 * *$ & -2.602 & $* *$ & -0.555 & & -0.501 & -0.499 & -0.388 & \\
\hline & (SE) & $(0.687)$ & & $(0.911)$ & $(0.938)$ & $(1.268)$ & & $(0.474)$ & & $(0.668)$ & $(0.539)$ & $(0.747)$ & \\
\hline & B & -0.415 & & -0.468 & -0.315 & -0.349 & & -0.192 & & -0.166 & -0.134 & -0.100 & \\
\hline \multirow[t]{3}{*}{ German legal origin } & $\mathrm{b}$ & -0.869 & & -1.108 & -0.914 & -1.153 & & -0.095 & & -0.169 & -0.114 & -0.197 & \\
\hline & (SE) & $(0.599)$ & & $(0.610)$ & $(0.669)$ & $(0.704)$ & & $(0.270)$ & & $(0.311)$ & $(0.278)$ & $(0.314)$ & \\
\hline & B & -0.083 & & -0.111 & -0.092 & -0.118 & & -0.018 & & -0.032 & -0.022 & -0.039 & \\
\hline \multirow{3}{*}{$\begin{array}{l}\text { Scandinavian legal } \\
\text { origin }\end{array}$} & $\mathrm{b}$ & -0.849 & & -0.479 & -1.614 & -0.849 & & -0.154 & & -0.051 & -0.128 & -0.261 & \\
\hline & (SE) & (1.039) & & $(0.994)$ & $(1.242)$ & $(1.105)$ & & $(0.660)$ & & $(0.656)$ & $(0.758)$ & $(0.676)$ & \\
\hline & B & -0.073 & & -0.043 & -0.146 & -0.079 & & -0.026 & & -0.009 & -0.022 & -0.046 & \\
\hline British legal origin (B & category & & & & & & & & & & & & \\
\hline Ethnolinguistic & $\mathrm{b}$ & -1.066 & & -1.018 & -1.198 & -0.866 & & -0.086 & & 0.119 & 0.094 & 0.435 & \\
\hline fractionalization & (SE) & $(0.681)$ & & $(0.777)$ & $(0.895)$ & $(0.941)$ & & $(0.384)$ & & $(0.399)$ & $(0.454)$ & $(0.441)$ & \\
\hline & B & -0.113 & & -0.110 & -0.130 & -0.094 & & -0.019 & & 0.027 & 0.022 & 0.100 & \\
\hline Natural resource & $\mathrm{b}$ & & & -0.653 & & -0.613 & & & & $-0.638 *$ & & -0.695 & \\
\hline abundance & (SE) & & & $(0.643)$ & & $(0.712)$ & & & & $(0.329)$ & & $(0.387)$ & \\
\hline & B & & & -0.065 & & -0.061 & & & & -0.150 & & -0.161 & \\
\hline Federal & $\mathrm{b}$ & & & 0.127 & & 0.060 & & & & -0.017 & & -0.060 & \\
\hline & (SE) & & & $(0.102)$ & & $(0.131)$ & & & & $(0.053)$ & & $(0.082)$ & \\
\hline & B & & & 0.103 & & 0.047 & & & & -0.027 & & -0.094 & \\
\hline Constant & $\mathrm{b}$ & -0.837 & & -1.226 & 2.232 & 0.806 & & 2.703 & $*$ & 1.751 & 1.932 & 2.077 & \\
\hline & (SE) & $(2.535)$ & & $(2.517)$ & $(4.126)$ & $(3.689)$ & & $(1.479)$ & & (1.789) & $(2.326)$ & $(2.316)$ & \\
\hline $\mathrm{N}$ & & 101 & & 91 & 86 & 81 & & 109 & & 101 & 96 & 91 & \\
\hline P-value for overident & tion test & & & & 0.122 & 0.079 & & & & & 0.512 & 0.326 & \\
\hline
\end{tabular}

Note: IV regressions 1, 2, 5, and 6 instrumented Gini (1971-96) with Mature cohort size (1971-96). IV regressions 3, 4, 7, and 8 instrumented Gini (71-96), ln GDPpc (71-96), and ln Open (71-96) with Mature cohort size, Latitude, Malaria index, and Constructed openness. 
Table A8. OLS and IV Regressions for Less and More Democratic Countries

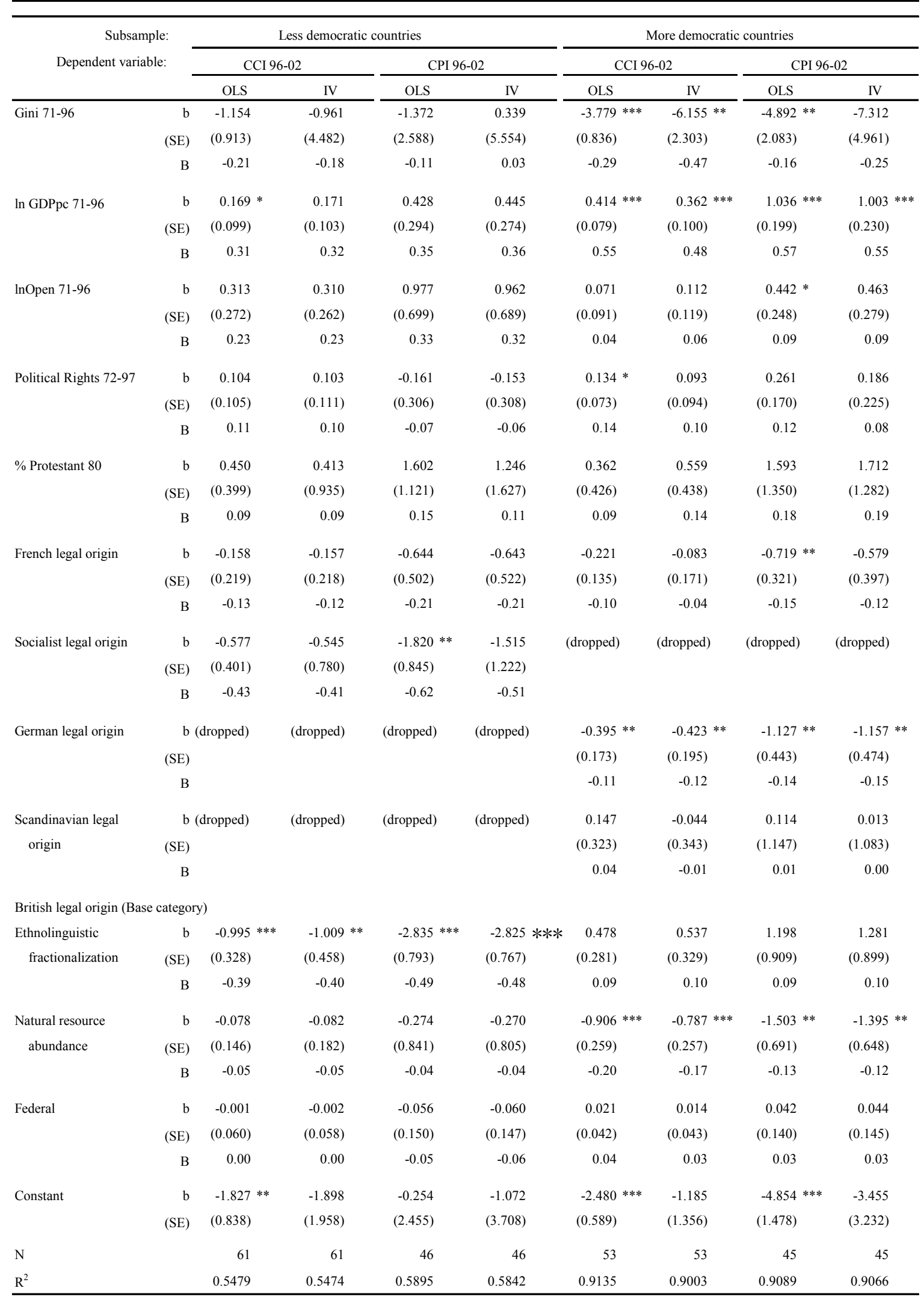

Note: The subsamples of more democratic countries and less democratic countries were divided at the political rights score (average for 1972-96) of four. For IV regressions, Gini (71-96) is instrumented with Mature cohort size (71-96). 
Table A9. OLS \& IV Regression Results for High-Income vs Low-Income Countries

\begin{tabular}{|c|c|c|c|c|c|c|c|c|c|c|c|c|c|}
\hline \multirow{2}{*}{\multicolumn{2}{|c|}{$\begin{array}{r}\text { Subsample: } \\
\text { Dependent variable: }\end{array}$}} & \multicolumn{5}{|c|}{ Low-income countries } & \multicolumn{7}{|c|}{ High-income countries } \\
\hline & & \multicolumn{3}{|c|}{ CCI 96-02 } & \multicolumn{2}{|c|}{ CPI 96-02 } & \multicolumn{3}{|c|}{ CCI 96-02 } & \multicolumn{4}{|c|}{ CPI 96-02 } \\
\hline & & OLS & & IV & OLS & IV & OLS & & IV & OLS & & IV & \\
\hline \multirow[t]{3}{*}{ Gini 71-96 } & $\mathrm{b}$ & -0.381 & & -1.314 & 1.012 & 2.182 & -3.173 & $* *$ & -7.014 & -5.323 & & -16.294 & \\
\hline & (SE) & $(0.526)$ & & $(2.662)$ & $(2.484)$ & $(3.619)$ & $(1.314)$ & & $(6.872)$ & $(3.449)$ & & $(22.178)$ & \\
\hline & B & -0.116 & & -0.400 & 0.117 & 0.251 & -0.308 & & -0.681 & -0.225 & & -0.689 & \\
\hline \multirow[t]{3}{*}{ ln GDPpc 71-96 } & $\mathrm{b}$ & -0.006 & & -0.020 & 0.015 & 0.038 & 0.557 & $* * *$ & 0.382 & 1.168 & $* *$ & 0.658 & \\
\hline & (SE) & $(0.066)$ & & $(0.069)$ & $(0.253)$ & $(0.262)$ & $(0.183)$ & & $(0.390)$ & $(0.548)$ & & $(1.161)$ & \\
\hline & B & -0.016 & & -0.053 & 0.016 & 0.038 & 0.496 & & 0.341 & 0.474 & & 0.267 & \\
\hline \multirow[t]{3}{*}{ lnOpen 71-96 } & $\mathrm{b}$ & 0.180 & $* *$ & $0.213 *$ & $0.808 * *$ & $0.743 *$ & 0.230 & & 0.151 & 0.617 & $*$ & 0.298 & \\
\hline & (SE) & $(0.088)$ & & $(0.116)$ & $(0.363)$ & $(0.410)$ & $(0.157)$ & & $(0.170)$ & $(0.338)$ & & $(0.637)$ & \\
\hline & B & 0.265 & & 0.314 & 0.448 & 0.412 & 0.128 & & 0.084 & 0.150 & & 0.073 & \\
\hline \multirow[t]{3}{*}{ Political Rights 72-97 } & $\mathrm{b}$ & -0.018 & & -0.007 & -0.183 & -0.202 & -0.097 & & -0.187 & -0.123 & & -0.405 & \\
\hline & (SE) & $(0.047)$ & & $(0.057)$ & $(0.169)$ & $(0.174)$ & $(0.131)$ & & $(0.236)$ & $(0.293)$ & & $(0.719)$ & \\
\hline & B & -0.073 & & -0.028 & -0.264 & -0.292 & -0.171 & & -0.327 & -0.096 & & -0.317 & \\
\hline \multirow[t]{3}{*}{$\%$ Protestant 80} & $\mathrm{~b}$ & -0.695 & $* *$ & -0.454 & -1.648 & -2.286 & 0.723 & & 0.976 & 2.118 & $*$ & 2.774 & \\
\hline & (SE) & $(0.289)$ & & $(0.740)$ & $(2.682)$ & $(2.715)$ & $(0.485)$ & & $(0.783)$ & $(1.223)$ & & (2.019) & \\
\hline & B & -0.270 & & -0.176 & -0.182 & -0.252 & 0.190 & & 0.257 & 0.256 & & 0.335 & \\
\hline \multirow[t]{3}{*}{ French legal origin } & $\mathrm{b}$ & -0.018 & & 0.015 & -0.293 & -0.357 & -0.304 & $*$ & -0.273 & -1.073 & $* *$ & -0.955 & $*$ \\
\hline & (SE) & $(0.099)$ & & $(0.130)$ & $(0.392)$ & $(0.412)$ & $(0.177)$ & & $(0.189)$ & $(0.466)$ & & $(0.529)$ & \\
\hline & B & -0.029 & & 0.023 & -0.181 & -0.220 & -0.143 & & -0.129 & -0.229 & & -0.203 & \\
\hline \multirow[t]{3}{*}{ Socialist legal origin } & $\mathrm{b}$ & -0.257 & & -0.348 & -0.794 & -0.702 & -1.385 & $* *$ & -2.219 & -3.002 & $* *$ & -5.392 & \\
\hline & (SE) & $(0.182)$ & & $(0.351)$ & $(0.634)$ & $(0.675)$ & $(0.565)$ & & (1.704) & $(1.297)$ & & $(5.208)$ & \\
\hline & B & -0.298 & & -0.404 & -0.384 & -0.340 & -0.557 & & -0.893 & -0.560 & & -1.006 & \\
\hline \multirow[t]{3}{*}{ German legal origin } & & dropped) & & (dropped) & (dropped) & (dropped) & -0.691 & $* *$ & $-0.741 * *$ & -1.602 & $* * *$ & -1.667 & $* *$ \\
\hline & (SE) & & & & & & $(0.273)$ & & $(0.363)$ & $(0.574)$ & & $(0.793)$ & \\
\hline & B & & & & & & -0.200 & & -0.215 & -0.217 & & -0.226 & \\
\hline \multirow{3}{*}{$\begin{array}{l}\text { Scandinavian legal } \\
\text { origin }\end{array}$} & & dropped) & & (dropped) & (dropped) & (dropped) & -0.423 & & -0.610 & -0.929 & & -1.249 & \\
\hline & (SE) & & & & & & $(0.372)$ & & $(0.567)$ & $(1.046)$ & & $(1.356)$ & \\
\hline & B & & & & & & -0.111 & & -0.160 & -0.114 & & -0.153 & \\
\hline \multicolumn{14}{|c|}{ British legal origin (Base category) } \\
\hline \multirow{3}{*}{$\begin{array}{l}\text { Ethnolinguistic } \\
\text { fractionalization }\end{array}$} & $\mathrm{b}$ & -0.330 & $*$ & -0.287 & -1.084 & -1.052 & -0.735 & & -0.441 & -0.766 & & 0.322 & \\
\hline & (SE) & $(0.182)$ & & $(0.247)$ & $(0.752)$ & $(0.705)$ & $(0.716)$ & & $(0.718)$ & $(1.569)$ & & $(2.344)$ & \\
\hline & $\mathrm{B}$ & -0.262 & & -0.228 & -0.332 & -0.322 & -0.144 & & -0.086 & -0.065 & & 0.027 & \\
\hline \multirow{3}{*}{$\begin{array}{l}\text { Natural resource } \\
\text { abundance }\end{array}$} & $\mathrm{b}$ & -0.079 & & -0.083 & 0.046 & 0.132 & -0.779 & $* *$ & -0.573 & -0.653 & & -0.281 & \\
\hline & (SE) & $(0.059)$ & & $(0.064)$ & $(0.656)$ & $(0.674)$ & $(0.320)$ & & $(0.511)$ & $(1.150)$ & & $(1.443)$ & \\
\hline & B & -0.105 & & -0.110 & 0.014 & 0.040 & -0.185 & & -0.136 & -0.060 & & -0.026 & \\
\hline \multirow[t]{3}{*}{ Federal } & $\mathrm{b}$ & 0.084 & $* * *$ & $0.073 *$ & 0.167 & 0.178 & 0.025 & & 0.020 & -0.001 & & -0.007 & \\
\hline & (SE) & $(0.031)$ & & $(0.041)$ & $(0.130)$ & $(0.120)$ & $(0.071)$ & & $(0.061)$ & $(0.172)$ & & $(0.153)$ & \\
\hline & B & 0.334 & & 0.290 & 0.267 & 0.285 & 0.049 & & 0.040 & -0.001 & & -0.006 & \\
\hline Constant & $\mathrm{b}$ & -0.805 & & -0.521 & 0.529 & 0.233 & -2.820 & & 0.856 & -3.449 & & 7.592 & \\
\hline & (SE) & $(0.487)$ & & $(0.897)$ & $(2.255)$ & $(2.264)$ & $(2.248)$ & & (7.196) & $(6.076)$ & & (22.981) & \\
\hline $\mathrm{N}$ & & 60 & & 60 & 42 & 42 & 54 & & 54 & 49 & & 49 & \\
\hline $\mathrm{R}^{2}$ & & 0.356 & & 0.320 & 0.284 & 0.279 & 0.802 & & 0.776 & 0.809 & & 0.773 & \\
\hline
\end{tabular}

Note: The subsamples of high-income and low-income countries were divided at the mean of the natural log of GDP per capita (avg. for 1971-96) of 7.57.

For IV regressions, Gini (71-96) is instrumented with Mature cohort size (71-96). 
Table A10. OLS Regressions of CCI and CPI with Interaction Terms

\begin{tabular}{|c|c|c|c|c|c|c|c|c|c|}
\hline \multirow{3}{*}{$\begin{array}{l}\text { Dependent variable } \\
\text { Gini } 71-96\end{array}$} & \multirow{3}{*}{ (SE) } & \multicolumn{4}{|c|}{ CCI 96-02 } & \multicolumn{4}{|c|}{ CPI 96-02 } \\
\hline & & -3.230 & $* * *$ & -3.162 & $* * *$ & -4.638 & $* * *$ & -4.184 & $* *$ \\
\hline & & $(0.683)$ & & $(0.666)$ & & $(1.647)$ & & (1.614) & \\
\hline \multirow{4}{*}{ ln GDPpc 71-96 } & $\mathrm{B}$ & -0.332 & & -0.324 & & -0.206 & & -0.186 & \\
\hline & $\mathrm{b}$ & 0.765 & $* * *$ & 0.323 & & 1.477 & $* * *$ & 0.246 & \\
\hline & (SE) & $(0.125)$ & & $(0.213)$ & & $(0.376)$ & & $(0.503)$ & \\
\hline & B & 1.174 & & 0.495 & & 0.984 & & 0.164 & \\
\hline \multirow[t]{3}{*}{ Political Rights 72-96 } & $\mathrm{b}$ & -0.005 & & 0.557 & $* * *$ & -0.076 & & 1.628 & $* * *$ \\
\hline & (SE) & $(0.065)$ & & $(0.206)$ & & $(0.157)$ & & $(0.516)$ & \\
\hline & B & -0.009 & & 1.049 & & -0.062 & & 1.311 & \\
\hline \multirow[t]{3}{*}{ Gini* (Pol Rights - 4) } & $\mathrm{b}$ & & & -1.378 & $* * *$ & & & -4.367 & $* * *$ \\
\hline & (SE) & & & $(0.482)$ & & & & $(1.347)$ & \\
\hline & B & & & -0.947 & & & & -1.202 & \\
\hline \multirow[t]{3}{*}{ Gini* (lnGDPpc - 7.57) } & $\mathrm{b}$ & -1.131 & $* * *$ & -0.129 & & -1.852 & $* *$ & 1.155 & \\
\hline & (SE) & $(0.311)$ & & $(0.512)$ & & $(0.826)$ & & $(1.204)$ & \\
\hline & B & -0.653 & & -0.075 & & -0.448 & & 0.279 & \\
\hline \multirow[t]{3}{*}{ InOpen 71-96 } & $\mathrm{b}$ & 0.115 & & 0.185 & & 0.717 & $* *$ & 0.867 & $* * *$ \\
\hline & (SE) & $(0.116)$ & & $(0.120)$ & & $(0.278)$ & & $(0.291)$ & \\
\hline & B & 0.059 & & 0.095 & & 0.160 & & 0.194 & \\
\hline \multirow[t]{3}{*}{$\%$ Protestant 80} & $\mathrm{~b}$ & 0.430 & & 0.397 & & 2.075 & $* *$ & 1.744 & $* *$ \\
\hline & (SE) & $(0.345)$ & & $(0.317)$ & & $(0.951)$ & & $(0.809)$ & \\
\hline & B & 0.091 & & 0.084 & & 0.198 & & 0.166 & \\
\hline \multirow[t]{3}{*}{ French legal origin } & $\mathrm{b}$ & -0.215 & & -0.194 & & -0.737 & $* *$ & -0.568 & $*$ \\
\hline & (SE) & $(0.130)$ & & $(0.134)$ & & $(0.297)$ & & $(0.317)$ & \\
\hline & B & -0.107 & & -0.097 & & -0.160 & & -0.123 & \\
\hline \multirow[t]{3}{*}{ Socialist legal origin } & $\mathrm{b}$ & -0.934 & $* * *$ & -0.572 & $*$ & -2.279 & $* * *$ & -1.147 & \\
\hline & (SE) & $(0.262)$ & & $(0.313)$ & & $(0.594)$ & & $(0.701)$ & \\
\hline & B & -0.356 & & -0.218 & & -0.408 & & -0.205 & \\
\hline \multirow[t]{3}{*}{ German legal origin } & $\mathrm{b}$ & -0.386 & & -0.392 & & -1.215 & $* *$ & -1.152 & $* *$ \\
\hline & (SE) & $(0.258)$ & & $(0.260)$ & & $(0.550)$ & & $(0.536)$ & \\
\hline & B & -0.079 & & -0.081 & & -0.122 & & -0.116 & \\
\hline \multirow{3}{*}{$\begin{array}{l}\text { Scandinavian legal } \\
\text { origin }\end{array}$} & $\mathrm{b}$ & 0.007 & & -0.037 & & -0.341 & & -0.237 & \\
\hline & (SE) & $(0.270)$ & & $(0.240)$ & & $(0.836)$ & & $(0.687)$ & \\
\hline & B & 0.001 & & -0.007 & & -0.031 & & -0.021 & \\
\hline \multicolumn{10}{|c|}{ British legal origin (Base category) } \\
\hline \multirow{3}{*}{$\begin{array}{l}\text { Ethnolinguistic } \\
\text { fractionalization }\end{array}$} & $\mathrm{b}$ & -0.414 & & -0.528 & $* *$ & -1.032 & & -1.151 & \\
\hline & (SE) & $(0.254)$ & & $(0.251)$ & & $(0.744)$ & & $(0.691)$ & \\
\hline & B & -0.105 & & -0.133 & & -0.112 & & -0.125 & \\
\hline \multirow{3}{*}{$\begin{array}{l}\text { Natural resource } \\
\text { abundance }\end{array}$} & $\mathrm{b}$ & -0.151 & & -0.202 & & -0.467 & & -0.497 & \\
\hline & (SE) & $(0.190)$ & & $(0.177)$ & & $(0.642)$ & & $(0.558)$ & \\
\hline & B & -0.052 & & -0.069 & & -0.046 & & -0.049 & \\
\hline \multirow[t]{3}{*}{ Federal } & $\mathrm{b}$ & 0.029 & & 0.030 & & 0.114 & & 0.109 & \\
\hline & (SE) & $(0.043)$ & & $(0.040)$ & & $(0.104)$ & & $(0.097)$ & \\
\hline & B & 0.051 & & 0.053 & & 0.092 & & 0.088 & \\
\hline \multirow[t]{2}{*}{ Constant } & $\mathrm{b}$ & -4.583 & $* * *$ & -3.783 & $* * *$ & -6.953 & $* *$ & -5.357 & $*$ \\
\hline & (SE) & $(0.926)$ & & $(1.038)$ & & $(3.091)$ & & (3.127) & \\
\hline $\mathrm{N}$ & & 114 & & 114 & & 91 & & 91 & \\
\hline $\mathrm{R}^{2}$ & & 0.812 & & 0.827 & & 0.814 & & 0.838 & \\
\hline
\end{tabular}


Table A11. OLS Regressions with Region Dummies

\begin{tabular}{|c|c|c|c|c|c|}
\hline \multirow{2}{*}{$\begin{array}{l}\text { Dependent variable: } \\
\text { Gini } 71-96\end{array}$} & \multicolumn{3}{|c|}{ CCI 96-02 } & \multicolumn{2}{|c|}{ CPI 96-02 } \\
\hline & b & $-1.562^{* * *}$ & $-2.344^{* * *}$ & $-2.929^{* *}$ & $-4.045 *$ \\
\hline & (SE) & $(0.514)$ & $(0.753)$ & $(1.257)$ & $(2.127)$ \\
\hline & B & -0.173 & -0.241 & -0.144 & -0.179 \\
\hline \multirow[t]{3}{*}{ In GDPpc 71-96 } & b & $0.343^{* * *}$ & $0.385^{* * *}$ & $0.805^{* * *}$ & $0.828^{* * *}$ \\
\hline & (SE) & $(0.082)$ & $(0.086)$ & $(0.199)$ & $(0.231)$ \\
\hline & B & 0.524 & 0.591 & 0.539 & 0.552 \\
\hline \multirow[t]{3}{*}{ Political Rights 72-96 } & b & 0.080 & 0.023 & 0.073 & 0.025 \\
\hline & (SE) & $(0.063)$ & $(0.072)$ & $(0.153)$ & $(0.186)$ \\
\hline & B & 0.152 & 0.044 & 0.060 & 0.020 \\
\hline \multirow[t]{3}{*}{ InOpen 71-96 } & b & $0.150 *$ & 0.161 & $0.600^{* * *}$ & $0.670^{* *}$ \\
\hline & (SE) & $(0.083)$ & $(0.109)$ & $(0.194)$ & $(0.259)$ \\
\hline & B & 0.081 & 0.083 & 0.142 & 0.150 \\
\hline \multirow[t]{3}{*}{$\%$ Protestant 80} & b & 0.408 & 0.421 & $2.128^{* * *}$ & $2.233 * *$ \\
\hline & (SE) & $(0.333)$ & $(0.320)$ & $(0.807)$ & $(0.929)$ \\
\hline & B & 0.085 & 0.089 & 0.202 & 0.213 \\
\hline \multirow[t]{3}{*}{ French legal origin } & $\mathrm{b}$ & -0.182 & $-0.194 *$ & $-0.648 * *$ & $-0.665 * *$ \\
\hline & (SE) & $(0.112)$ & $(0.112)$ & $(0.289)$ & $(0.293)$ \\
\hline & B & -0.091 & -0.097 & -0.140 & -0.144 \\
\hline \multirow[t]{3}{*}{ Socialist legal origin } & b & -0.029 & 0.275 & -0.062 & 0.175 \\
\hline & (SE) & $(0.264)$ & $(0.321)$ & $(0.620)$ & $(0.740)$ \\
\hline & B & -0.012 & 0.105 & -0.012 & 0.031 \\
\hline \multirow[t]{3}{*}{ German legal origin } & $\mathrm{b}$ & -0.269 & $-0.383 *$ & $-1.024 * *$ & $-1.195 * *$ \\
\hline & (SE) & $(0.201)$ & $(0.225)$ & $(0.455)$ & $(0.526)$ \\
\hline & B & -0.057 & -0.079 & -0.107 & -0.120 \\
\hline \multirow[t]{3}{*}{ Scandinavian legal origin } & b & -0.071 & -0.084 & -0.527 & -0.544 \\
\hline & (SE) & $(0.269)$ & $(0.250)$ & $(0.715)$ & $(0.795)$ \\
\hline & B & -0.012 & -0.016 & -0.045 & -0.049 \\
\hline \multicolumn{6}{|c|}{ British legal origin (Base category) } \\
\hline \multirow{3}{*}{$\begin{array}{l}\text { Ethnolinguistic } \\
\text { fractionalization }\end{array}$} & $\mathrm{b}$ & $-0.680^{* * *}$ & $-0.470 *$ & $-1.055 *$ & -0.798 \\
\hline & (SE) & $(0.200)$ & $(0.277)$ & $(0.607)$ & $(0.758)$ \\
\hline & B & -0.167 & -0.119 & -0.111 & -0.086 \\
\hline \multirow{3}{*}{$\begin{array}{l}\text { Natural resource } \\
\text { abundance }\end{array}$} & $\mathrm{b}$ & & $-0.433 * * *$ & & -0.785 \\
\hline & (SE) & & $(0.143)$ & & $(0.622)$ \\
\hline & B & & -0.148 & & -0.078 \\
\hline \multirow[t]{3}{*}{ Federal } & b & & 0.003 & & 0.039 \\
\hline & (SE) & & $(0.036)$ & & $(0.094)$ \\
\hline & B & & 0.006 & & 0.032 \\
\hline \multirow[t]{3}{*}{ East Asia \& Pacific } & b & -0.235 & -0.230 & -0.206 & -0.085 \\
\hline & (SE) & $(0.214)$ & $(0.231)$ & $(0.498)$ & $(0.545)$ \\
\hline & B & -0.080 & -0.076 & -0.031 & -0.012 \\
\hline East \& Central Europe & $\mathrm{b}$ & $-0.964 * * *$ & $-1.462 * * *$ & $-2.197 * * *$ & $-2.723 * * *$ \\
\hline & (SE) & $(0.257)$ & $(0.311)$ & $(0.608)$ & $(0.671)$ \\
\hline & B & -0.364 & -0.522 & -0.393 & -0.467 \\
\hline Middle East \& & $\mathrm{b}$ & -0.284 & -0.194 & -0.092 & 0.099 \\
\hline North Africa & (SE) & $(0.207)$ & $(0.237)$ & $(0.487)$ & $(0.566)$ \\
\hline & B & -0.073 & -0.053 & -0.010 & 0.011 \\
\hline South Asia & b & -0.241 & -0.268 & -0.917 & -0.909 \\
\hline & (SE) & $(0.300)$ & $(0.311)$ & $(0.721)$ & $(0.770)$ \\
\hline & в & -0.047 & -0.055 & -0.079 & -0.082 \\
\hline Sub-Saharan Africa & $\mathrm{b}$ & -0.029 & -0.026 & -0.106 & -0.012 \\
\hline & (SE) & $(0.249)$ & $(0.265)$ & $(0.531)$ & $(0.597)$ \\
\hline & B & -0.013 & -0.012 & -0.018 & -0.002 \\
\hline Latin America \& & $\mathrm{b}$ & $-0.625 * * *$ & $-0.498 * *$ & $-1.005 *$ & -0.688 \\
\hline Caribbean & (SE) & $(0.208)$ & $(0.214)$ & $(0.533)$ & $(0.577)$ \\
\hline & B & -0.244 & -0.201 & -0.173 & -0.123 \\
\hline Western Europe as base reg & & & & & \\
\hline Constant & $\mathrm{b}$ & $-2.140^{* * *}$ & $-1.967 * *$ & -2.194 & -2.127 \\
\hline & (SE) & $(0.688)$ & $(0.772)$ & (1.659) & $(1.897)$ \\
\hline $\mathrm{N}$ & & 129 & 114 & 102 & 91 \\
\hline $\mathrm{R}^{2}$ & & 0.832 & 0.842 & 0.847 & 0.845 \\
\hline
\end{tabular}


Table A12. OLS Regressions of GINI with CPI

\begin{tabular}{|c|c|c|c|c|c|}
\hline \multirow{3}{*}{ CPI 96-99 } & \multicolumn{3}{|c|}{ (1) } & \multicolumn{2}{|l|}{ (2) } \\
\hline & $\mathrm{b}$ & -1.857 & $* *$ & -1.361 & $*$ \\
\hline & (SE) & $(0.799)$ & & $(0.723)$ & \\
\hline & $\mathrm{B}$ & -0.385 & & -0.309 & \\
\hline \multirow[t]{3}{*}{ ln GDPpc 71-96 } & $\mathrm{b}$ & -0.845 & & -0.461 & \\
\hline & (SE) & (1.196) & & $(1.328)$ & \\
\hline & B & -0.114 & & -0.067 & \\
\hline \multirow[t]{3}{*}{ Political Rights 72-96 } & $\mathrm{b}$ & -0.995 & & -1.608 & \\
\hline & (SE) & $(1.175)$ & & $(1.098)$ & \\
\hline & $\mathrm{B}$ & -0.168 & & -0.290 & \\
\hline \multirow[t]{3}{*}{ lnOpen 71-96 } & $\mathrm{b}$ & 1.173 & & 0.410 & \\
\hline & (SE) & $(2.133)$ & & $(2.257)$ & \\
\hline & $\mathrm{B}$ & 0.059 & & 0.022 & \\
\hline \multirow[t]{3}{*}{$\%$ Protestant 80} & $\mathrm{~b}$ & 0.217 & $* *$ & 0.130 & $* *$ \\
\hline & (SE) & $(0.094)$ & & $(0.059)$ & \\
\hline & B & 0.448 & & 0.297 & \\
\hline \multirow[t]{3}{*}{ French legal origin } & $\mathrm{b}$ & 0.439 & & 0.823 & \\
\hline & (SE) & $(2.544)$ & & $(2.863)$ & \\
\hline & B & 0.019 & & 0.040 & \\
\hline \multirow[t]{3}{*}{ Socialist legal origin } & $\mathrm{b}$ & -14.116 & $* * *$ & -16.055 & $* * *$ \\
\hline & (SE) & $(2.917)$ & & $(3.623)$ & \\
\hline & $\mathrm{B}$ & -0.575 & & -0.689 & \\
\hline \multirow[t]{3}{*}{ German legal origin } & $\mathrm{b}$ & -8.860 & $* * *$ & -8.125 & $* *$ \\
\hline & (SE) & $(2.568)$ & & $(3.281)$ & \\
\hline & $\mathrm{B}$ & -0.169 & & -0.156 & \\
\hline \multirow{3}{*}{$\begin{array}{l}\text { Scandinavian legal } \\
\text { origin }\end{array}$} & $\mathrm{b}$ & -18.891 & $* *$ & -13.812 & $* *$ \\
\hline & (SE) & $(7.270)$ & & $(5.241)$ & \\
\hline & $\mathrm{B}$ & -0.361 & & -0.305 & \\
\hline \multicolumn{6}{|c|}{ British legal origin (Base category) } \\
\hline \multirow{3}{*}{$\begin{array}{l}\text { Ethnolinguistic } \\
\text { fractionalization }\end{array}$} & $\mathrm{b}$ & & & -1.458 & \\
\hline & (SE) & & & $(5.708)$ & \\
\hline & $\mathrm{B}$ & & & -0.036 & \\
\hline \multirow{3}{*}{$\begin{array}{l}\text { Natural resource } \\
\text { abundance }\end{array}$} & $\mathrm{b}$ & & & 0.021 & \\
\hline & (SE) & & & $(0.032)$ & \\
\hline & $\mathrm{B}$ & & & 0.048 & \\
\hline \multirow[t]{3}{*}{ Federal } & $\mathrm{b}$ & & & 0.146 & \\
\hline & (SE) & & & $(0.540)$ & \\
\hline & $\mathrm{B}$ & & & 0.027 & \\
\hline \multirow[t]{2}{*}{ Constant } & $\mathrm{b}$ & 53.938 & $* * *$ & 54.922 & $* * *$ \\
\hline & (SE) & $(9.571)$ & & (11.676) & \\
\hline $\mathrm{N}$ & & 87 & & 77 & \\
\hline $\mathrm{R}^{2}$ & & 0.501 & & 0.574 & \\
\hline
\end{tabular}

